\title{
PROCEDURY USTAWODAWCZE W PIERWSZYM SEJMIE ODRODZONEJ RZECZYPOSPOLITEJ POLSKIEJ (1919-1922). REGULACJA PRAWNA I PRAKTYKA PARLAMENTARNA
}

\author{
LEGISLATIVE PROCEDURES IN THE FIRST SEJM \\ OF THE RENASCENT REPUBLIC OF POLAND (1919-1922). \\ LEGAL REGULATIONS AND PARLIAMENTARY PRACTICE
}

From its onset, the Legislative Sejm 1919-1922 took on all the fundamental functions of a parliament in a constitutional state, the most important of which was the legislative competence. The constituent assembly was forced to establish the legal rules of the functioning of the state as a whole, and to lay down the procedures of its own work. The legal-positive foundation of those procedures was rather modest. It comprised fragmentary regulations in the so-called small constitution of 20 February 1919, several ordinary statutes delegating competences to pass acts in the form of decrees and extraordinary legislation to the executive power, as well the most complex but incomplete norms included in the provisional regulations of the Legislative Sejm of 14 February 1919. The deficiency of legal-positive regulation, apparent in numerous situations, had to be overcome by parliamentary practice referring to solutions applied in regulations and parliamentary customs of the Western states, particularly partitioning powers, in representations previously peopled by some Deputies of the constituent assembly, but also France and, incidentally, other countries. The chamber established its own solutions and customs relatively quickly and some of them lasted until the end of the interwar period. The legislative proceedings included numerous procedures: general, applied to pass ordinary statutes, and particular, i.e. legislative procedures to pass the constitution and the budget. The latter also included proceedings comprising elements of oversight and legislative procedure, such as the procedure of granting the consent to ratify international agreements and the procedure of approving the decree legislation passed by the executive. All procedures could be shortened (shortened proceedings) or accelerated (urgency clause), just as all comprised distinguished stages: the first reading of a bill held at a plenary session (Deputies' bills preferred); committee works on the bill; second reading before the whole chamber, beginning with a committee report, followed by a general, then a detailed debate, and partial, then general vote; third reading, sometimes preceded by an additional stage of committee works, and often automatically commenced immediately after the second reading; promulgation of an act by the Marshal of the Sejm and ordering its publication in the official gazette.

Słowa kluczowe: czytania projektu ustawy, inicjatywa ustawodawcza, komisje sejmowe, konstytuanta, mała konstytucja z 1919 r., marszałek Sejmu, ogólna procedura ustawodawcza, poseł sprawozdawca, postępowanie ustawodawcze, praktyka parlamentarna, prawo pozytywne, prawo zwyczajowe, procedura budżetowa, procedura skrócona, tryb ustawodawczy, tymczasowy regulamin obrad Sejmu Ustawodawczego, uchwalanie konstytucji, ustawodawstwo dekretowe, wniosek nagły, wniosek poselski, zgoda na ratyfikację umów międzynarodowych, źródła prawa

Key words: reading of a bill, legislative initiative, Sejm committees, constituent assembly, small constitution of 1919, Marshal of the Sejm, general legislative procedure, Deputy-Rapporteur, parliamentary practice, positive law, custom law, budget procedure, shortened proceedings, legislative procedure, provisional regulations of the Legislative Sejm, passing of a constitution, decree legislation, urgent motion, Deputy's motion, consent to ratify an international agreement, sources of law

* Dr hab. Piotr A. Tusiński, prof. Uniwersytetu Pedagogicznego im. KEN w Krakowie, Instytut Prawa, Administracji i Ekonomii, ptusinski@up.krakow.pl 


\section{WPROWADZENIE}

Darlament działający w ramach systemu odpowiedzialności rządu (casus

1 III Republiki Francuskiej), jak również w warunkach jego odmiany zracjonalizowanej po I wojnie światowej (w republikach: weimarskiej i austriackiej oraz szeregu państw Europy Środkowo-Wschodniej, w tym w Polsce) ${ }^{1}$ pełnił szereg funkcji ustrojowych, z których najistotniejsze były kompetencje: ustawodawcza, kontrolna i kreacyjna ${ }^{2}$. Funkcje te, charakterystyczne dla parlamentu mieszczącego się w ramach pouvoir constitué, a więc związanego przepisami konstytucji i usytuowanego obok innych organów konstytucyjnych, cechowały parlament wywindowany do roli suwerena, a więc konstytuantę. Dla każdej ze wspomnianych funkcji ustrojowych charakterystyczne było działanie zgodne z określonym trybem postępowania (procedury parlamentarnej), rozumianego jako regulowany normami prawa i zwyczajami zbiór czynności, układających się w sukcesywny (sekwencyjny, etapowy) łańcuch decyzyjny i podejmowanych wyłącznie przez podmioty wskazane normami kompetencyjnymi, w kolejności wyznaczonej normami formalnymi i organizacyjnymi, prowadzący do załatwienia (rozstrzygnięcia) jakiejś sprawy mieszczącej się w uprawnieniach parlamentu ${ }^{3}$.

W ramach funkcji ustawodawczej Sejm Ustawodawczy Rzeczypospolitej Polskiej [dalej: SU] stosował kilka procedur parlamentarnych — procedurę ustawodawcza ogólną (w zakresie uchwalania ustaw zwykłych) oraz procedury szczególne: ustawodawczą w sprawie uchwalenia konstytucji (część doktryny wyróżnia nawet w związku z tym osobną funkcję parlamentu bądź procedurę parlamentarna, procedurę ustrojodawcza) i procedurę budżetową ${ }^{4}$. Do grupy procedur szczególnych należy również zaliczyć procedury łączące w sobie elementy postępowania kontrolnego sensu stricto z elementami postępowania ustawodawczego, do których można zaliczyć procedurę wyrażania zgody na ratyfikację umów międzynarodowych i procedurę zatwierdzania ustawodawstwa dekretowego stanowionego przez egzekutywę.

\section{KONSTYTUCYJNE ŹRÓDLA PRAWA PROCEDUR USTAWODAWCZYCH}

Procedury parlamentarne stosowane w SU w latach 1919-1922 były regulowane aktami normatywnymi rangi konstytucyjnej, ustawami zwykłymi, aktem wewnętrznego prawa parlamentarnego (regulaminem izby) oraz normami prawa zwyczajowego. Charakterystyczną cechą regulacji pozytywnoprawnych z tego zakresu prawa było łączenie w jednym akcie norm formalnoprawnych z przepisami materialnoprawnymi

1 J. Stembrowicz, Rzad w systemie parlamentarnym, Warszawa 1982, s. 60 i n.

2 B. Banaszak, Prawo konstytucyjne, Warszawa 2012, s. 435-438.

3 Vide m.in.: Stownik języka polskiego, t. 2: L-P, Warszawa 1979, s. 926; E. Kustra, Proces ustawodawczy jako proces decyzyjny, „Acta Universitatis Nicolai Copernici. Prawo XII. Nauki Humanistyczno-Społeczne" 1973, z. 56, s. 110; P.A. Tusiński, Postępowanie ustawodawcze w Sejmie i w Senacie II Rzeczypospolitej 1919-1939. Prawo - zwyczaje — praktyka parlamentarna, Radom 2008, s. 25.

4 Confer P.A. Tusiński, op. cit., s. 257-259. 
w każdym z wymienionych typów prawodawstwa. Postępowanie ustawodawcze z racji wiodącej kompetencji ustrojowej izby, jaką była funkcja ustawodawcza, podlegało najszerszej regulacji normatywnej. W okresie bezpośrednio poprzedzającym zebranie się SU oraz w trakcie jego kadencji obowiązywały trzy akty prawne pełniące rolę prowizorycznej (tymczasowej) konstytucji. Pierwszym był wydany 3 stycznia $1918 \mathrm{r}$. przez Radę Regencyjną dekret o tymczasowej organizacji władz naczelnych w Królestwie Polskim 5 . Drugim ustanowiony przez Radę Ministrów i Tymczasowego Naczelnika Państwa dekret z dnia 22 listopada 1918 r. o najwyższej władzy reprezentacyjnej Republiki Polskiej ${ }^{6}$. Trzecim uchwała Sejmu z dnia 20 lutego 1919 r. o powierzeniu Józefowi Piłsudskiemu dalszego sprawowania urzędu Naczelnika Państwa [dalej: mała konstytucja z 20 lutego 1919 r.] $]^{7}$.

Dekret z 3 stycznia 1918 r. o tymczasowej organizacji władz naczelnych w Królestwie Polskim miał fundamentalne znaczenie dla kształtu ustrojowego rządu do czasu wejścia w życie ustawy zasadniczej z 17 marca 1921 r. ${ }^{8}$, a częściowo — jako podstawa prawna działalności szeregu ministerstw - zachował aktualność nawet do końca międzywojnia. Dekretem powierzono władzę zwierzchnią w Królestwie Radzie Regencyjnej [dalej: RR], która miała ją sprawować za pośrednictwem prezydenta Rady Ministrów (premiera) oraz poszczególnych ministrów. Wszelkie akty RR musiały być kontrasygnowane przez prezydenta ministrów.

Problematykę ,ustawodawstwa zwykłego" uregulowano w art. 3 dekretu z dnia 22 listopada 1918 r. o najwyższej władzy reprezentacyjnej Republiki Polskiej. Dekrety, zwane projektami ustawodawczymi oraz ustawami, były uchwalane przez Radę Ministrów i zatwierdzane przez Tymczasowego Naczelnika Państwa9. Uzyskiwały one moc obowiązującą z chwilą ogłoszenia ich w „Dzienniku Praw Państwa Polskiego", chyba że same stanowiły inaczej. Moc tę uzyskiwały tymczasowo, pod rygorem jej utraty, na okres do dnia pierwszego posiedzenia SU, na którym miały być mu przedstawione do zatwierdzenia. Notabene przepis ten został dokładnie powtórzony za dekretem RR z dnia 15 października 1918 r., dotyczącym ustawodawstwa tymczasowego, w którym ta ogłosiła się organem władzy uprawnionym do stanowienia rozporządzeń z mocą ustawy ${ }^{10}$. Przepis obligujący do przedstawienia dekretów Sejmowi do zatwierdzenia na pierwszym jego posiedzeniu miał, jak się wkrótce okazało, charakter głównie proceduralny, ponieważ SU na swoim pierwszym posiedzeniu ograniczył się tylko do odczytania przez tymczasowego sekretarza obrad, posła Mieczysława Niedziałkowskiego, spisu przedłożonych przez rząd 216 dekretów RR

5 „Dziennik Praw Królestwa Polskiego” [dalej: Dz.P.K.P.] z 1918 r. nr 1, poz. 1. Treść dekretu omawia: W. Komarnicki, Polskie prawo polityczne (Geneza i system), Warszawa 1922, s. 44-47.

6 „Dziennik Praw Państwa Polskiego” [dalej: Dz.P.P.P.] z 1918 r. nr 17, poz. 41.

7 Uchwała Sejmu z dnia 20 lutego 1919 roku o powierzeniu Józefowi Piłsudskiemu dalszego sprawowania urzędu Naczelnika Państwa, Dz.P.P.P. nr 19, poz. 226.

${ }^{8}$ Ustawa z dnia 17 marca 1921 roku Konstytucja Rzeczypospolitej Polskiej, Dz.U. nr 44, poz. 267.

9 Confer R. Kraczkowski, Dekretowanie ustaw w Polsce w latach 1918-1926, Warszawa 1994, s. $32-33$.

${ }^{10}$ Dekret z dnia 15 października $1918 \mathrm{r}$. w przedmiocie tymczasowego wykonywania władzy ustawodawczej, Dz.P.K.P. nr 12, poz. 24; R. Kraczkowski, op. cit., s. 29 i 33. 
i Tymczasowego Naczelnika Państwa oraz przyją je „do ustawowego traktowania”, czyli zatwierdzenia w trybie ustawodawczym, a nie kontrolnym. Na 3. posiedzeniu Sejm skierował wszystkie te dekrety do świeżo powołanej ze swego grona Komisji Prawniczej, która miała je ewentualnie przesłać dalej do innych komisji wedle ich właściwości przedmiotowej ${ }^{11}$. Praca nad tymi dekretami trwała w następnych tygodniach i miesiącach funkcjonowania konstytuanty, co oznaczało rozciagnięcie ich mocy obowiązującej poza dzień 10 lutego 1919 r., kiedy SU zainaugurował swe obrady. Więcej o aspektach procedury rozpatrywania tych dekretów przez konstytuantę będzie dalej.

Uchwalona przez SU 20 lutego 1919 r. mała konstytucja była w sprawach ustawodawstwa niemal równie enigmatyczna jak dekret z 22 listopada 1918 r. W jej artykule II, w zadaniu pierwszym, zapowiadano uchwalenie konstytucji w sposób „ustawowy”, a w konstytucji miano zawrzeć ,zasadniczo przepisy o organizacji naczelnych władz w Państwie Polskim”. W 1. punkcie powołanego artykułu określono SU jako władzę ,suwerenną i ustawodawczą" oraz ustanowiono, że uchwalane przez Sejm „ustawy” ogłasza marszałek Sejmu. Jak zauważono w literaturze, „Mała konstytucja nie określała zakresu przedmiotowego ustawodawstwa ani przypadków wyłączności ustawy. Sejm Ustawodawczy był suwerenny: mając nieoznaczone kompetencje mógł zastrzec do swej decyzji każdą sprawę. Konsekwencją utrzymania w mocy dotychczasowego porządku prawnego była jednak konieczność sięgania po formę ustawy w tych wszystkich sprawach, które zostały uregulowane aktami ustawodawczymi zaborców. Drugą grupę stanowiły materie, które stały się już przedmiotem ustawodawstwa Sejmu bądź zostały uregulowane dekretami Tymczasowego Naczelnika Państwa lub Rady Regencyjnej. Trzecią natomiast były te, które zgodnie z panującymi poglądami winny być uregulowane ustawowo"12. W niewielkim tylko zakresie deficyt regulacji materii ustawodawczej w małej konstytucji usunięto jej nowelizacją z 13 lutego 1920 r. ${ }^{13}$, w której postanowiono, że: „Emisja biletów Polskiej Krajowej Kasy Pożyczkowej lub innych biletów, obciążających Skarb Państwa, nie mniej zaciaganie pożyczek państwowych, tudzież przyjmowanie przez Państwo gwarancji finansowych nie może nastapić bez uprzedniego zezwolenia Sejmu".

Uchwała SU z 20 lutego 1919 r. formalnie nie miała rangi ustawy, ale zarówno w ówczesnej doktrynie, jak i w praktyce ustrojowej nie podważano jej rangi konstytucyjnej. Częściowo ten formalny mankament małej konstytucji usunięto ustawą przechodnią z dnia 18 maja $1921 \mathrm{r} .{ }^{14}$, uchwaloną w związku z zamierzonym vacatio legis dla konstytucji z 17 marca 1921 r. Ustawa ta ze względu na jej treść normatywną niewątpliwie miała charakter ustawy konstytucyjnej. W art. 1 powołanej ustawy stano-

${ }_{11}$ R. Kraczkowski, op. cit., s. 34.

${ }^{12}$ Ibidem, s. 45.

${ }^{13}$ Uchwała Sejmu z dnia 13 lutego 1920 r. uzupełniająca uchwałę Sejmu z dnia 20 lutego 1919 r. o powierzeniu Józefowi Piłsudskiemu dalszego sprawowania urzędu Naczelnika Państwa, Dz.U. nr 17, poz. 84.

${ }^{14}$ Ustawa przechodnia z dnia 18 maja 1921 r. do ustawy konstytucyjnej z dnia 17 marca 1921 r. w sprawie tymczasowej organizacji władzy zwierzchniej Rzeczypospolitej, Dz.U. nr 44, poz. 268. 
wiono, że: „Sejm Ustawodawczy sprawuje swą władzę w dotychczasowym zakresie do chwili ukonstytuowania się władzy ustawodawczej na zasadach ustawy konstytucyjnej z dnia 17 marca 1921 roku", przez co pośrednio nadano sankcję ustawy konstytucyjnej tym przepisom uchwały z 20 lutego 1919 r., które określały kompetencje konstytuanty ${ }^{15}$.

\section{USTAWOWE ŹRÓDLA PRAWA PROCEDUR PARLAMENTARNYCH}

Deficyt unormowań ustroju państwa określonego w przepisach małej konstytucji z 20 lutego 1919 r. wypełniały w pewnej mierze, choć w zakresie dalekim od wyczerpującego, przepisy niektórych ustaw zwykłych — zarówno utrzymanych w mocy z poprzednich okresów ustrojowych, jak i uchwalanych przez konstytuantę - oraz przede wszystkim przepisy tymczasowego regulaminu obrad Sejmu Ustawodawczego Rzeczypospolitej Polskiej, uchwalonego 14 lutego 1919 r. ${ }^{16}$

Ustawy zwykłe okresu konstytuanty o materii ustawodawstwa traktowały jedynie w odniesieniu do tzw. ustawodawstwa delegowanego, zwanego też dekretowym. Z jednej strony przepisy te upoważniały organy władzy wykonawczej do dekretowania ustaw, zawężając tym samym przedmiotowo i czasowo kompetencję ustawodawczą parlamentu bądź lokując ją niejako konkurencyjnie w rękach egzekutywy, z drugiej zaś nakładały na te organy obowiązki związane z przedstawianiem dekretów do wiadomości bądź zatwierdzenia przez Sejm. Ta ostatnia kwestia implikowała uprawnienia Sejmu do uchylania tych dekretów w odpowiedniej formie i procedurze.

W okresie obowiazzywania małej konstytucji z 20 lutego 1919 r. SU uchwalił w sumie 10 ustaw upoważniających rząd (Radę Ministrów i poszczególnych ministrów) do stanowienia ustawodawstwa dekretowego (mówiąc ściśle, jedna z nich dotyczyła nadania ministrowi przemysłu i handlu uprawnień do regulowania w rozporządzeniach spraw opałowych, które to pełnomocnictwo, funkcjonujące 21 miesięcy, zaliczono w literaturze do prawodawstwa wyjattkowego, a nie delegowanego), a czterokrotnie uchwalenia takiej delegacji odmówił ${ }^{17}$. Częściowo podobny do delegacji ustawodawczej ustanowionej we wspomnianych ustawach pod rządami małej konstytucji charakter - przynajmniej w zakresie czasowego ograniczenia kompetencji ustawodawczej Sejmu - miały tzw. akty prawotwórstwa wyjątkowego, stanowione przez Radę Obro-

15 W czerwcu 1922 r. o włączeniu przepisów małej konstytucji do ,wielkiej konstytucji” na mocy ustawy przechodniej z 18 maja 1921 r. był przekonany poseł H. Lieberman: vide sprawozdanie stenograficzne z posiedzenia Sejmu Ustawodawczego [dalej: spr. sten. SU] z 321. posiedzenia z 23 czerwca 1922 r., ł. 6.

16 Tymczasowy regulamin obrad Sejmu Ustawodawczego Rzeczypospolitej Polskiej, Sejm Ustawodawczy Rzeczypospolitej Polskiej 1919-1922, druk nr 1; ,Tymczasowy regulamin obrad Sejmu Ustawodawczego Rzeczypospolitej Polskiej z uwzględnieniem zmian...”, Sejm Ustawodawczy RP, druk nr 1, Warszawa 15 września 1921 r. Pierwotny tekst regulaminu opublikował też T. Rzepecki: Sejm Rzeczypospolitej Polskiej 1919 roku, Poznań 1920, s. 40-48. Tekst regulaminu wraz z wykazem jego nowelizacji — notabene w ujęciu nierzetelnym, z błędami i pominięciami — w opracowaniu T. Koperskiej opublikowano też w „Przeglądzie Sejmowym” 1993, nr 1, s. 99-110.

${ }_{17}$ Regulacje te, jak również przedłożenia odrzucone przez Sejm oraz pełnomocnictwa opałowe omawia R. Kraczkowski, op. cit., s. 46-56, 78-80. 
ny Państwa [dalej: ROP] ${ }^{18}$. Na mocy ustawy z dnia 1 lipca 1920 r. o utworzeniu Rady Obrony Państwa ${ }^{19}$ stała się ona tymczasowym organem władzy ustawodawczej i wykonawczej, któremu podlegała Rada Ministrów. Rada, wykonując funkcje ustawodawcze, miała prawo do wydawania rozporządzeń z tymczasową mocą ustaw. Tymczasowa, ponieważ rozporządzenia te wymagały następczego zatwierdzenia przez SU i miały mu być w tym celu przedstawiane na najbliższym posiedzeniu po ich wyda$\mathrm{niu}^{20}$. Podstawowe aspekty postępowania sejmowego w tym zakresie omówiono dalej. Należy również zauważyć, że SU — niezależnie od wspomnianych ustaw — niepublikowaną w „Dzienniku Ustaw” uchwała (sic!) z dnia 1 sierpnia 1919 r. upoważnił ministra skarbu do tymczasowego regulowania stosunków celnych w drodze rozporządzeń (z obowiązkiem ich publikacji w „Dzienniku Ustaw”), a więc udzielił mu faktycznie pełnomocnictw dekretowych ${ }^{21}$.

\section{POSTĘPOWANIE USTAWODAWCZE W PRZEPISACH TYMCZASOWEGO REGULAMINU OBRAD SU ORAZ PRAKTYKI PARLAMENTARNEJ}

Wobec znaczącego deficytu regulacji kwestii ustroju państwa w przepisach małej konstytucji z 20 lutego 1919 r. oraz incydentalnego podejmowania materii dotyczącej ustawodawstwa i kontroli rządu w ustawach zwykłych podstawowe zadanie reglamentacji prawnej ich aspektów formalnych (a częściowo również materialnoprawnych) spoczęło na tymczasowym regulaminie obrad SU. Brak regulacji odnoszących się do postępowania ustawodawczego w małej konstytucji z 20 lutego 1919 r. sprawił, że pod jej rządami jedynym źródłem pozytywnego prawa parlamentarnego, normującego niektóre kwestie materialnoprawne dotyczące ustawodawstwa oraz przebieg procedury ustawodawczej w SU, był regulamin izby. Tymczasowy regulamin obrad SU do chwili wejścia w życie konstytucji marcowej pozostawał w zasadzie jedynym aktem normującym szczegółowe kompetencje, strukturę wewnętrzną i procedury pracy SU. Charakterystyczne, że regulamin ten dotyczył nie tylko obrad Sejmu, ale również wielu innych istotnych kwestii ustrojowych oraz że — mimo zaznaczonej w tytule ,tymczasowości" - stanowił on podstawę funkcjonowania konstytuanty do końca jej działania $^{22}$. Tymczasowy regulamin obrad był w zakresie postępowania ustawodawczego

${ }^{18}$ Formalnie natomiast nie miały charakteru aktów ustawodawczych (dekretów), lecz rozporządzeń wykonawczych, wspomniane rozporządzenia ministra przemysłu i handlu wydawane w ramach nadzwyczajnych pełnomocnictw opałowych, na podstawie ustawy z dnia 14 lipca 1920 r. w sprawie udzielenia Ministrowi Przemysłu i Handlu nadzwyczajnych pełnomocnictw do uregulowania spraw opałowych, Dz.U. nr 75, poz. 508 , ze zm.).

19 Dz.U. nr 53, poz. 327.

${ }^{20}$ Confer R. Kraczkowski (op. cit., s. 58-59); P.K. Marszałek, Rada Obrony Państwa z 1920 roku. Studium prawnohistoryczne, „Acta Universitatis Wratislaviensis” 1995, Prawo CCXXVIII, passim.

${ }_{21}$ Vide spr. sten. z 83. posiedzenia SU, 1 sierpnia 1919 r., ł. 15-39.

${ }^{22}$ Zgodnie z art. 1 tymczasowego regulaminu miał on obowiązywać do chwili uchwalenia przez Sejm ostatecznego regulaminu na wniosek Komisji Regulaminowej. Nie nastapiło to jednak do końca funkcjonowania konstytuanty. Już 4 sierpnia 1919 r. posłowie Związku Ludowo-Narodowego [dalej: ZLN] zgłosili wniosek w sprawie uchwalenia stałego regulaminu Sejmu w formie ustawy, z załączonym do niego projektem (druk nr 969). Wniosek nie doczekał się jednak rozpatrzenia. 
trzykrotnie (w niewielkim stosunkowo zakresie) nowelizowany uchwałami izby podjętymi w dniach 24 marca 1920 r., 21 stycznia i 1 marca 1921 r. ${ }^{23}$

Mimo relatywnie rozbudowanej i szczegółowej — w porównaniu z innymi procedurami parlamentarnymi - reglamentacji prawnej postępowania ustawodawczego okresu konstytuanty w przepisach pozytywnego prawa parlamentarnego (głównie w regulaminie sejmowym) trudno uznać ją za wyczerpująca. Tu i ówdzie w tym niewątpliwie złożonym trybie procedowania występowały znaczące luki regulacyjne oraz sformułowania nieostre, z których tylko niewielka część doczekała się do końca kadencji SU uściśleń poprzez nowelizację regulaminu. Zasadniczą większość tych niedostatków musiano przezwyciężyć w praktyce parlamentarnej wypracowywanej ad hoc na rodzimym gruncie bądź sięgając do zapożyczeń z norm zwyczajowego prawa parlamentarnego państw wzorcowych dla odradzającego się parlamentaryzmu polskiego (głównie Prus i II Rzeszy Niemieckiej, Austrii i autonomicznej Galicji oraz Francji).

Obserwacja praktyki parlamentarnej w okresie konstytuanty pozwala na sformułowanie spostrzeżenia, że postępowanie ustawodawcze przebiegało w trzech fazach: przygotowawczej, obejmującej czynności sporządzenia projektu ustawy ${ }^{24}$ oraz wykonania inicjatywy ustawodawczej; głównej, obejmującej trzy czytania projektu na forum plenarnym i rozdzielające czytania plenarne prace $\mathrm{w}$ komisji/komisjach sejmowych; oraz w kończącej bieg postępowania fazie promulgacji i ogłoszenia ustawy, obejmującej podpisanie projektu przez marszałka Sejmu i zarządzenie jego ogłoszenia w „Dzienniku Ustaw” przez prezydenta Rady Ministrów ${ }^{25}$.

Warto podkreślić, że pewna część przepisów tymczasowego regulaminu obrad SU, odnoszących się do ustawodawstwa, w warunkach sygnalizowanej wcześniej zwięzłości regulacyjnej małej konstytucji miała de facto i de iure charakter przepisów materialnoprawnych i wkraczała w obszar normowany zwykle ustawą zasadniczą. Niewątpliwie taki charakter miały przepisy art. 15 i 16 regulaminu, normujące zagadnienie podmiotów inicjatywy, sensu largo wnioskodawczej, a sensu stricto ustawodawczej. Rozróżnienie obu zakresów przedmiotowych inicjatywy jest o tyle istotne, że w regulaminie tego nie zrobiono. Ustanowiono tylko $\mathrm{w}$ jego art. 15, że przedmiotem obrad Sejmu mógł być „,wniosek” rządu, komisji sejmowej, ewentualnie większości lub mniejszości komisji oraz posła. Natomiast w art. 38 regulaminu ustanowiono, że „projekty ustaw podlegają trzem czytaniom”, pozostałe wnioski więc, a contrario, nie musiały im podlegać, co potwierdziła w całej rozciagłości praktyka parlamentarna okresu konstytuanty. Jest przy tym oczywiste (dowodem na to są druki SU), że tylko część z wniosków, które wpływały do laski marszałkowskiej, zawierała w załączeniu projekty ustaw. Zgodnie z art. 15 i 16 tymczasowego regulaminu obrad SU inicjatywa wnioskodawcza (w tym ustawodawcza) przysługiwała:

${ }^{23}$ A. Gwiżdż, Formy pracy sejmów Drugiej Rzeczypospolitej, [w:] Sejmy Drugiej Rzeczypospolitej, red. A. Zakrzewski, Warszawa 1990, s. 126.

${ }^{24} \mathrm{~W}$ praktyce parlamentarnej już od zarania prac konstytuanty przyjmowano, że projekt ustawy musi być sformułowany normatywnie.

${ }^{25}$ Szczegółowo o całym przebiegu postępowania ustawodawczego w SU oraz w izbach parlamentarnych następnych kadencji vide P.A. Tusiński, op. cit., passim. 
rządowi ${ }^{26}$, komisji sejmowej, większości komisji sejmowejj ${ }^{27}$, mniejszości komisji oraz grupie co najmniej 15 posłów ${ }^{28}$. Projekt musiał być zgłoszony na piśmie (w tym przypadku był to już wymóg odnoszący się tylko do formy projektu). Poselskie przedłożenie ustawodawcze musiało być zaopatrzone w podpisy popierających je posłów ${ }^{29}$.

Odnośnie do samej instytucji wniosku parlamentarnego (w tym ustawodawczego) w okresie konstytuanty należy podkreślić, że zwiększeniu siły jego oddziaływania, ale przede wszystkim przyspieszeniu uchwalenia, służyła przewidziana w art. 35 regulaminu instytucja trybu nagłego (nadawanego na przedstawiony marszałkowi, na piśmie wraz z załączeniem motywów, wniosek rządu lub 30 posłów), wyraźnie wzorowana na parlamentaryzmie austriackim ${ }^{30}$. W pierwszych tygodniach obrad konstytuanty zgłoszone w takim trybie wnioski marszałek poddawał pod głosowanie na forum plenarnym, w celu nadania im klauzuli nagłości ${ }^{31}$, ale odstępował od wymogu głosowania i ograniczał się do podania stosownej informacji o przesłaniu wniosku w trybie nagłym wprost do komisji, jeśli został on podpisany przez posłów z kilku dużych klubów wraz z ich przywódcami, co niewątpliwie rokowało poparcie wniosku ${ }^{32}$. Już pierwsze dni działalności SU przyniosły bardzo dużą liczbę wniosków uznanych przez ich inicjatorów za nagłe ${ }^{33}$. W następstwie tego w praktyce nastapiła zmiana wykładni przepisu art. 35 regulaminu stosowanej przez Konwent Seniorów ${ }^{34}$. W nowej wykładni (wyraźnie praeter legem) przyjęto, że zaopatrzenie wniosku w 30 podpisów jest wystarczającym i automatycznym wymogiem upoważniającym do nadania mu klauzuli nagłości, bez konieczności zatwierdzenia jej przez izbę. Stanowiło też upoważnienie do przesłania wniosku przez marszałka bezpośrednio do komisji, po poinformowaniu o tym posłów na posiedzeniu plenarnym izby ${ }^{35}$. W pierwszym roku funk-

${ }^{26}$ Rząd w opisywanym okresie korzystał z niej zasadniczo (ale, jak się okazało, z licznymi wyjątkami) in collegio; vide P.A. Tusiński, op. cit., s. 87-109.

${ }^{27}$ Użyte w cytowanym przepisie zwroty „komisji” i ,większości komisji” na oznaczenie dwóch różnych podmiotów inicjatywy ustawodawczej były w praktyce rozróżnieniem pozornym. W gruncie rzeczy mógł to być wyłącznie jeden i ten sam podmiot, bowiem komisja mogła zająć stanowisko tylko większością głosów swych członków.

${ }^{28}$ Było to wyraźne nawiązanie do niemieckiej tradycji parlamentarnej, gdzie przyjęto dokładnie taki sam wymóg. Różnica dotyczyła jednak możliwości wnoszenia poprawek do projektu ustawy, ponieważ w Niemczech mógł to uczynić nawet pojedynczy poseł, podczas gdy w SU co najmniej 15; confer H.J. Schreiner, Procedury w niemieckiej tradycji parlamentarnej, „Przegląd Sejmowy” 1994, nr 4, s. 50-51.

${ }^{29}$ Na temat inicjatywy ustawodawczej łącznie z jej obrazem statystycznym vide P.A. Tusiński, op. cit., s. $87-114$.

${ }^{30}$ Confer S. Głąbiński, Wspomnienia polityczne, Pelplin 1939, s. 123; W. Witos, Moje wspomnienia, Warszawa 1978, s. 288.

31 Np. spr. sten. z 4. posiedzenia SU, 22 lutego 1919 r., ł. 97-98, 100, 151.

32 Spr. sten. z: 17. posiedzenia SU, 21 marca 1919 r., ł. 915-916; z 23. posiedzenia SU, 1 kwietnia 1919 r., ł. 53; z 85. posiedzenia SU, 1 października 1919 r., 1. 29.

${ }_{33}$ Zwracał na to zjawisko uwagę marszałek W. Trąmpczyński, apelując do posłów o umiar; vide spr. sten. z 6. posiedzenia SU, 25 lutego 1919 r., ł. 202.

34 Szerzej o konwencie vide P.A. Tusiński, Norma prawna i obyczaj jako podstawa wyłaniania i funkcjonowania organów kierowniczych parlamentu II Rzeczypospolitej, „Prace Naukowe Politechniki Radomskiej im. Kazimierza Pułaskiego: Ekonomika" 1999, nr 1, s. 94-99.

35 Spr. sten. z 40. posiedzenia SU, 22 maja 1919 r., ł. 67-68 oraz z 42. posiedzenia SU, 27 maja 1919 r., 1. 65 . 
cjonowania SU utarł się zwyczaj, że tryb nagły zatwierdzano na plenum tylko w przypadku wniosków o charakterze stricte politycznym, a o postawieniu sprawy na porządku dziennym decydował dyskrecjonalnie marszałek Sejmu ${ }^{36}$, ale już wiosną 1920 r. zwyczaj ten rozszerzono również na wnioski o charakterze ekonomicznym ${ }^{37}$. Zgodnie ze stanowiskiem Konwentu Seniorów z lata 1920 r., jeśli wnioskodawcy domagali się dyskusji nad trybem nagłym na forum plenarnym, to uprawnienie do nadania tego trybu przechodziło z marszałka na izbę. W październiku tego roku Konwent postanowił dodatkowo, że nad trybem nagłym miano dyskutować na plenum izby dopiero po uprzednim przedstawieniu wniosku przedstawicielom poszczególnych klubów w celu zapoznania się z nim$^{38}$. Natomiast w przypadku wniosków nieroztrząsanych na plenum, konwent - aby uniknąć niespodzianek — postanowił sam nadawać klauzulę nagłości ${ }^{39}$. Zebranie pod wnioskiem 30 podpisów w celu uznania trybu nagłego wcale nie było trudne, zważywszy na zasadę wzajemności. W ten sposób z formy kwalifikowanej, jaką niewątpliwie chcieli mu nadać twórcy regulaminu, wniosek nagły stał się instytucją stosowaną na co dzień. Posłowie wobec nawału wniosków nagłych doskonale zdawali sobie sprawę, że brak zgody Sejmu na nadanie wnioskowi trybu nagłego i traktowanie go jak zwykłego wniosku praktycznie oznaczało jego ,pogrzebanie”. Stąd większość spośród ponad 2 tys. wniosków zgłaszanych w konstytuancie uznawano nie całkiem formalnie - za wnioski zgłaszane w trybie nagłym ${ }^{40}$. Główny cel zgłaszających taki wniosek, czyli przyspieszenie procedowania, wobec równoczesnego niewyznaczenia komisji terminu na przedstawienie sprawozdania $\mathrm{w}$ jego sprawie, nie był osiagany. W praktyce nadanie trybu nagłego najczęściej nie wpływało bowiem na przyspieszenie uchwalenia ustaw $\mathrm{y}^{41}$. Podejmowane w SU próby ograniczenia tego zjawiska nie przynosiły jednak zadowalających rezultatów do końca jego funkcjonowania ${ }^{42}$.

W regulaminie SU w ogóle nie unormowano zagadnienia związanego z wykonaniem inicjatywy ustawodawczej, pozostawiając tę materię — jak zresztą wiele innych

${ }^{36}$ Konwent Seniorów postanowił nawet 23 marca 1920 r., że klauzula nagłości może przysługiwać tylko wnioskom dotyczącym zagadnień ogólnopolitycznych i tylko takie miały być umieszczane w porządku dziennym obrad Sejmu; vide „Kurier Polski” nr 83, 24 III 1920 r. Marszałek Trąmpczyński dopuszczał apelację od swojej decyzji o nieumieszczeniu dyskusji w sprawie klauzuli nagłości wniosku na forum plenarnym do Konwentu Seniorów. Przyznawał też, że omawiana kompetencja doskwiera mu i postulował przeniesienie jej na Sejm; vide spr. sten. SU ze 163. posiedzenia, 14 lipca 1920 r., 1. 80 oraz spr. sten. z 238. posiedzenia SU, 23 czerwiec 1921 r., 1. 64.

${ }_{37}$ Spr. sten. ze 139. posiedzenia SU, 23 kwietnia 1920 r., 1. 68.

38 Spr. sten. ze 170. posiedzenia SU, 7 października 1920 r., ł. 48.

39 Spr. sten. z 48. posiedzenia SU, 12 czerwca 1919 r., ł. 60; z 49. posiedzenia, 13 czerwca 1919 r., ł. 56; „Kurier Polski” nr 192, 16 VII 1920, oraz nr 263, 25 IX 1920.

40 Sejm Ustawodawczy Rzeczypospolitej Polskiej. Skorowidz rzeczowy do sprawozdań stenograficznych z posiedzeń plenarnych Sejmu pos. 1 (10.II.1919)_pos. 342 (27.XI.1922), Kancelaria Sejmu PRL, Warszawa 1972, maszynopis w Bibliotece Sejmowej [dalej: Skorowidz], s. XXVII-XXVIII.

${ }^{41}$ Zwrócił na to zjawisko uwagę sprawozdawca Komisji Regulaminowej Sejmu I kadencji, przedstawiając projekt regulaminu Sejmu w lutym 1923 r. i podkreślając, że posłowie konstytuanty zdawali sobie sprawę z problematycznej klauzuli nagłości wniosków tak określanych, a składali je mimo to w celach demonstracyjnych; spr. sten z 16. posiedzenia Sejmu I kad., 16 lutego 1923 r., 1. 10. Confer też: L. Zieleniewski, Regulaminy Sejmu i Senatu, „Nowe Państwo” 1936, t. IV, z. 2, s. 47.

${ }^{42}$ Z. Kaczmarek, Wojciech Trampczyński, Poznań 1993, s. 128. 
szczegółowych aspektów procedury ustawodawczej — praktyce parlamentarnej ${ }^{43}$. Nie uwzględniono też możliwości wycofania projektu ustawy przez wnioskodawcę i jego ewentualnych dalszych losów, np. wskutek podtrzymania wniosku przez inny podmiot wyposażony w prawo inicjatywy ustawodawczej.

Szczątkowe tylko materiały źródłowe SU, obrazujące jego prace wewnętrzne, ale też inne źródła pośrednio dotyczące tego zagadnienia nie pozwalają na prześledzenie całości działań marszałka i ewentualnie Komisji Regulaminowej i Nietykalności Poselskiej, składających się na wykonanie inicjatywy ustawodawczej. Na etap ten składały się takie czynności, jak: wniesienie projektu do laski marszałkowskiej; badanie zgodności projektu z konstytucją przez marszałka (i ewentualnie Komisję Regulaminowa); badanie projektu w aspekcie jego poprawności formalno-legislacyjnej (wniesienie na piśmie, sformułowanie normatywne, załączenie odpowiedniej liczby odpisów projektu, załączenie uzasadnienia, opatrzenie projektu odpowiednią liczbą podpisów posłów w przypadku inicjatywy poselskiej lub promowanie projektu przez właściwego ministra, powołującego się na stosowną uchwałę Rady Ministrów o wystapieniu z rządowym projektem ustawy; promowanie projektu przez przewodniczącego komisji, powołującego się na stosowną uchwałę komisji o wystapieniu z własnym projektem ustawy itp.); ewentualna korespondencja i bezpośrednie spotkania marszałka z wymienionymi podmiotami inicjatywy ustawodawczej w celu wyjaśnienia wątpliwości powstających na tym etapie procedury.

W odniesieniu do wykonania inicjatywy ustawodawczej w okresie prac SU udało się natrafić jedynie na wątek dotyczący badania konstytucyjności zgłaszanych projektów ustaw. W tym względzie precedensowa była rezolucja Komisji Skarbowo-Budżetowej SU z 4 października 1921 r., dotycząca kontroli projektów ustaw na etapie prac komisyjnych po pierwszym czytaniu na posiedzeniu plenarnym. Sprawa dotyczyła badania zgodności projektów ustaw z art. 10 konstytucji marcowej. Tekst rezolucji był następujący: „,Komisja Skarbowo-Budżetowa powinna każdy wniosek i projekty ustaw jej przedkładane zbadać przede wszystkim czy są zgodne z art. 10 Konstytucji i w tym wypadku, jeżeli wnioski te lub ustawy pociaggają za sobą wydatki ze Skarbu Państwa, lecz nie podają sposobu ich pokrycia, odsyłać je inicjatorom dla ich uzupełnienia w myśl żądań Konstytucji”"44. Jednomyślne uchwalenie tej rezolucji przez Sejm ${ }^{45}$ dzisiaj budzi poważne wątpliwości prawne, wówczas jednak ich nie dostrzeżono. Stosowanie rezolucji w praktyce oznaczałoby wydłużenie jednej z czynności etapu wykonania inicjatywy ustawodawczej do fazy już po przyjęciu ustawy w pierwszym czytaniu, wkraczałoby w kompetencje przyznane regulaminem Sejmu (co prawda expressis verbis dopiero od lutego 1923 r.) jego marszałkowi i przyznawałoby komisji uprawnienie do eliminowania pro-

${ }^{43} \mathrm{~W}$ projekcie regulaminu SU Związek Ludowo-Narodowy proponował nowe przepisy materialnoprawne rangi konstytucyjnej, np. zakładał wymóg formy ustawowej dla każdego wniosku, ,którego przyjęcie przez Sejm powoduje normę prawną dla postępowania rządu, lub obywateli, albo pociagga za sobą wydatek ze Skarbu Państwa przekraczający sto tysięcy złotych w stosunku rocznym” (art. 53).

44 A. Wierzbicki, Wspomnienia, t. II, s. 256-257, maszynopis w Bibliotece Instytutu Historii Polskiej Akademii Nauk w Warszawie.

${ }^{45}$ Spr. sten z 250. posiedzenia SU, 4 października 1921 r., 1. 33-35. 
jektów ustaw, która to kompetencja przysługiwała tylko izbie. Nie jest też jasne, czy tej procedurze miały podlegać także rządowe projekty ustaw, czy tylko poselskie. Nie bez znaczenia pozostaje wreszcie antycypowanie w rezolucji mocy obowiązującej konstytucji marcowej, wbrew przepisom ustawy przechodniej z 18 marca $1921 \mathrm{r}$.

Przepisy odnoszące się do szeroko pojętej procedury ustawodawczej wypełniały zasadniczą część tymczasowego regulaminu obrad. Były one treścią aż 43 spośród 65 artykułów zamieszczonych w rozdziałach: „Posiedzenia”; „Prezydium urzędujące”, „Porządek dzienny”, „Wnioski nagłe”, „Ustawy”, „Głosowanie”, „Komisje”, „Protokoły i stenogramy posiedzeń". Większość z tych 43 artykułów dotyczyła unormowania postępowania ustawodawczego sensu stricto oraz procedowania pozostałych różnorakich wniosków, niemających charakteru ustawodawczego, a także spraw wynikających z pozostałych funkcji konstytuanty, a więc: interpelacji, rezolucji, wystąpień przedstawicieli rządu, wniosków w sprawie wotum nieufności, wniosków w sprawach personalnych itp.

Wspólne przepisy normowały zagadnienia dotyczące:

— jawności (tajności) posiedzeń (art. 4), przy czym w regulaminie postanowiono, że w trybie tajnym nie można było przeprowadzać głosowania „nad żadną ustawa”;

- języka rozpraw, którym był język polski (art. 5);

- sposobu ustalania porządku dziennego posiedzenia i jego przedmiotu (art. 11 i 15), przy czym zgodnie z pierwszym z powołanych przepisów porządek dzienny ustalał marszałek i przedstawiał go Sejmowi do zatwierdzenia bądź zmiany, w drugim zaś mówiąc o przedmiocie obrad, określano enumeratywnie podmioty inicjatywy wnioskodawczej (ustawodawczej), o czym już była mowa;

- udzielania głosu poza porządkiem dziennym (art. 13 i 29) na najwyżej 5 minut w sprawie formalnej, w celu sprostowania i złożenia oświadczenia osobistego;

- kworum (art. 14), które wynosiło przynajmniej 100 posłów;

- poselskiej inicjatywy wnioskodawczej (art. 16), która przysługiwała co najmniej 15 posłom;

- zapisywania się do głosu, listy mówców, kolejności i sposobu przemawiania (art. 17-25 i 28);

- zgłaszania poprawek (art. 26-27), które mogły być zgłaszane „w ten sam sposób, co i wnioski samodzielne", czyli przez minimum 15 posłów;

- wniosków formalnych (art. 30-34) o: zamknięcie dyskusji, przejście do punktu porządku dziennego, przerwanie dyskusji, odesłanie do komisji, odroczenie dyskusji, głosowanie bez dyskusji, głosowanie w całości (en bloc), zmianę porządku dziennego, przywołanie do porządku i wnioski „do prowadzenia obrad”, oraz sposobu procedowania w ich sprawie;

- wniosków w trybie nagłym (art. 35-36);

- techniki głosowania (art. 46-48), czyli głosowania: ,przez powstanie z miejsc”, obliczenie przez sekretarzy ${ }^{46}$ oraz głosowanie imienne;

${ }^{46} \mathrm{~W}$ praktyce sejmowej ustalanie wyniku głosowania przez obliczenie odbywało się metodą,,przez drzwi”, polegającej na wyjściu wszystkich posłów z sali plenarnej i wchodzeniu na nią przez dwoje drzwi z napisami ,tak” i ,nie”. 
— organizacji i regulacji obrad komisji sejmowych (art. 49-53);

— a także protokołów i stenogramów posiedzeń (art. 65), z nakazem ich sporządzania oraz po nowelizacji regulaminu opatrywania ich w załączeniu tekstami wniosków i interpelacji poselskich.

Do przebiegu procesu ustawodawczego odnosił się wprost tylko jeden rozdział regulaminu, zatytułowany „Ustawy”, obejmujący art. 38-44. W powołanych przepisach ustanowiono dwie procedury postępowania ustawodawczego w Sejmie: zwykłą i skrócona. Obydwie obejmowały trzy czytania projektu ustawy, ale procedura skrócona dawała możliwości przyspieszania biegu postępowania przez rezygnację z niektórych działań podejmowanych podczas procedowania w trybie zwykłym, ustanawiania terminów dla komisji lub skracania biegu niektórych terminów.

Skutkiem prawnym (pozytywnym) wykonania inicjatywy ustawodawczej było uruchomienie następnego stadium postępowania ustawodawczego w Sejmie — fazy głównej. Pierwszą czynnością fazy głównej było zlecenie przez marszałka druku projektu ustawy i doręczenie go posłom ,,co najmniej na 24 godziny przed postawieniem jej na porządku dziennym” (art. 39 in medio regulaminu). Oczywiście dotyczyło to wszystkich podmiotowo wyróżnionych typów inicjatywy ustawodawczej, z wyjątkiem posiłkowej (związanej) inicjatywy komisyjnej, w której debata nad wnioskiem wzywającym do przygotowania projektu ustawy zastępowała pierwsze czytanie, a właściwy projekt powstawał na etapie prac w komisji. Po tej pierwszej czynności fazy głównej postępowanie ustawodawcze w sprawie danego projektu mogło biec dalej wskutek wyznaczenia daty pierwszego czytania i przystapienia do niego. Do pierwszego czytania projektu mogło jednak nie dojść, jeśli został on wycofany przez wnioskodawcę. Niestety nie udało się potwierdzić w źródłach występowania takich przypadków w czasie prac konstytuanty.

Pierwsze czytanie projektu ustawy na posiedzeniu plenarnym obejmowało rozprawę „nad całością ustawy” (,bez rozpraw co do szczegółów ustawy”) i kończyło się jego odrzuceniem ${ }^{47}$ albo przesłaniem do określonej komisji (art. 38-39) ${ }^{48}$. W ujęciu przedstawiciela przedwojennej doktryny pierwsze czytanie projektu ustawy miało dać odpowiedź na pytanie, ,czy parlament chce się w ogóle projektem zająć”49. Przepisy regulaminu dotyczące pierwszego czytania były bardzo nieprecyzyjne. Deficyt ten szybko przezwyciężono, ponieważ już pod koniec funkcjonowania konstytuanty zaczęto wyraźnie różnicować pierwsze czytanie rządowego projektu ustawy od czytania

${ }^{47} \mathrm{~W}$ art. 39 regulaminu oraz innych jego przepisach w rozdziale „Ustawy” nie posłużono się jednak terminem ,projekt ustawy”, lecz ,ustawa”. Tymczasem akt prawny stawał się ustawą w znaczeniu formalnym dopiero wówczas, gdy przeszedł pełną ścieżkę legislacyjną i został, zgodnie z dyspozycją art. II pkt 1 zd. 2 małej konstytucji, ogłoszony przez marszałka Sejmu.

${ }^{48} \mathrm{~W}$ projekcie regulaminu SU, zgłoszonym przez ZLN, postulowano obowiązek przesłania projektu ustawy przyjętego w pierwszym czytaniu prezydentowi ministrów „dla zakomunikowania Rządowi, który powinien swoje wobec niej stanowisko określić w komisji i wyłuszczyć Izbie przed drugim czytaniem. Żadna ustawa nie może być w drugim czytaniu uchwalona bez wysłuchania przez Sejm opinii o niej Rządu" (art. 56). Każdy projekt ustawy, której wykonanie miało pociągnąć za sobą wydatek ze Skarbu Państwa, musiał być przesyłany dodatkowo do — oprócz właściwej komisji — Komisji Skarbowo-Budżetowej, której opinia była niezbędna, aby przejść do głosowania w drugim czytaniu (art. 55).

49 Z. Cybichowski, Polskie prawo państwowe na tle uwag z dziedziny nauki o państwie i porównawczego prawa państwowego, t. II, Warszawa 1933, s. 108. 
projektu poselskiego. W praktyce znacząco uprzywilejowywano wnioski poselskie, które na forum plenarnym były poddawane tylko pewnym formalnym czynnościom, bardzo uproszczonym, wręcz rutynowym, o wybitnie informacyjnym charakterze. Warto też podkreślić, że w procedurze pierwszych czynności postępowania z wnioskami poselskimi nie rozróżniano wniosków zawierających projekty ustaw od tych, w których tylko wzywano do przedłożenia projektu przez rząd lub komisję czy też wniosków służących innym celom. Rządowe projekty ustaw podlegały natomiast, co najmniej od 1922 r., typowym — przynajmniej w kontekście przepisów regulaminu - czynnościom charakterystycznym dla pierwszego czytania.

Pierwsze czytanie wniosku poselskiego, z nielicznymi tylko przykładami odstępstw od tej reguly, w latach prac konstytuanty odbywało się na końcu plenarnego posiedzenia izby i było przedostatnim lub jednym z ostatnich punktów porządku dziennego. Polegało na odczytaniu przez marszałka (sekretarza obrad) samego tytułu wniosku i poinformowaniu, do której komisji sejmowej został on skierowany ${ }^{50}$. W odniesieniu do wniosków nagłych w regulaminie (art. 36) przewidziano możliwość uzasadnienia tego trybu prac przez wnioskodawcę w 5-minutowym wystapieniu oraz, w takim samym czasie, ewentualne wystapienie mówcy, który opowiadał się przeciwko temu trybowi. Wnioskodawca mógł - i robiono to stosunkowo często - oprócz samego uzasadniania nagłego trybu procedowania poruszyć także aspekty zasadności merytorycznej projektu. Podobnie jego adwersarz. Obaj mówcy nie mogli jednak wchodzić w szczegóły projektu ${ }^{51}$. Ta krótka debata kończyła się głosowaniem, ale tylko dotyczącym nadania klauzuli nagłości, a nie meritum projektu. Nad meritum głosowano czasami bezpośrednio po zatwierdzeniu trybu nagłego, ale tylko jeśli wniosek nie zawierał załączonego projektu ustawy. Na koniec marszałek oznajmiał, że wniosek, jako nagły lub zwykły (gdy Sejm nie nadał mu klauzuli nagłości) został skierowany do danej komisji. Oznaczało to, że wniosek poselski, a tym samym załączony do niego poselski projekt ustawy, nie mógł zostać odrzucony przez izbę w pierwszym czytaniu, czyli zawsze przechodził do etapu prac komisyjnych. $\mathrm{Na}$ tym właśnie polegało uprzywilejowanie poselskich projektów ustaw w stosunku do projektów rządowych. Dostrzegając to, rząd również zaczął podążać tą drogą. Niektóre projekty ustaw gabinet przedkładał jako wnioski nagłe, przez co mogły być one poddawane pierwszemu czytaniu już na tym posiedzeniu plenarnym, na którym zostały wniesione. Wnoszonych w tym trybie rządowych projektów ustaw nie poddawano debacie, lecz marszałek odsyłał je bezpośrednio do właściwej komisji, po poinformowaniu o tym Sejmu. Niektórzy posłowie próbowali przeciw temu protestować, ale praktyka ta szybko się przyjęła, a marszałek zaczął się nawet powoływać na ten zwyczaj. Trzeba jednak podkreślić, że przedkładanie rządowych projektów ustaw

50 Confer Skorowidz, s. XXVII.

51 Już na początku obrad konstytuanty zwracał na to uwagę marszałek: „Muszę P. Posłom przypomnieć, żeby w swoich przemówieniach nie zapominali o koniecznej pewnej celowości, zatem w sprawach, które odsyła się do komisji nie powinni Panowie Posłowie zanadto wchodzić w szczegóły"; vide spr. sten. z 14. posiedzenia SU, 14 marca 1919 r., 1. 731. 
w formie wniosków w trybie nagłym ograniczano do projektów pilnych, a przez to wyjątkowych i relatywnie rzadkich ${ }^{52}$.

W pierwszym roku funkcjonowania SU rządowe projekty ustaw były poddawane pierwszemu czytaniu zazwyczaj na końcu posiedzenia plenarnego. Po roku zaczęła się kształtować praktyka, wyraźnie już ugruntowana na początku 1921 r., umieszczania pierwszego czytania rządowych projektów ustaw na początku posiedzenia plenarnego, w zasadzie w pierwszym punkcie merytorycznych obrad. Natomiast terminu dostarczenia posłom druków projektów ustaw na 24 godziny przed pierwszym czytaniem dotrzymywano rzadko, rozdając stosowne druki tuż przed otwarciem posiedzenia lub nawet $\mathrm{w}$ jego trakcie. Pierwsze czytanie rządowego projektu (zgłoszonego w trybie zwykłym, a nie nagłym) w znakomitej większości przypadków polegało na odczytaniu przez marszałka tytułu projektu ustawy i poinformowaniu, do której komisji jest on kierowany. Brak wystapień posłów na etapie pierwszego czytania rządowego projektu ustawy, a tym samym debaty, najczęściej oznaczał brak głosowania za odrzuceniem $^{53}$ bądź odesłaniem projektu do właściwej komisji. Wobec braku głosów sprzeciwu marszałek decydował nie tylko o formalnym przejściu projektu przez etap pierwszego czytania, ale również o wyznaczeniu właściwej — jego zdaniem — komisji w celu jego dalszego procedowania ${ }^{54}$. Sam marszałek już w marcu 1920 r. powoływał się na stosowny zwyczaj w tym zakresie.

Zwyczaj ograniczania pierwszego czytania rządowego projektu ustawy do informacji o jej tytule i odesłaniu do komisji - wykształcony w początkach konstytuanty i naruszany niezwykle rzadko — zaczęto jednak zmieniać w końcowym okresie funkcjonowania SU. Wówczas coraz więcej rządowych projektów ustaw budziło poważne zainteresowanie posłów, którzy zapisywali się u sekretarza obrad do głosu. Zapisy te były sygnałem, że nad projektem, a ściślej nad jego zasadami ogólnymi i celowością, odbędzie się debata. Już od początków prac konstytuanty debaty te często wynikały z życzenia ministra, który zawczasu chciał poznać opinię Sejmu na temat projektu ${ }^{55}$.

52 Confer: spr. sten. z 53. posiedzenia SU, 18 czerwca 1919 r., 1. 58; spr. sten. z 63. posiedzenia SU, 4 lipca 1919 r., ł. 66; spr. sten. z 69. posiedzenia SU, 15 lipca 1919 r., ł. 58; spr. sten. z 75. posiedzenia SU, 22 lipca 1919 r., ł. 2; spr. sten. z 88. posiedzenia SU, 14 października 1919 r., ł. 33; spr. sten. z 91. posiedzenia SU, 24 października 1919 r., 1. 9; spr. sten. z 243. posiedzenia SU, 28 lipca 1921 r., 1. 8.

53 Sporadycznie pojawiały się jednak wnioski poselskie o odrzucenie rządowego projektu ustawy w pierwszym czytaniu, ale zazwyczaj nie znajdowały one poparcia większości, np.: spr. sten. z 215. posiedzenia SU, 4 marca 1921 r., ł. 13; spr. sten. z 260. posiedzenia SU, 15 listopada 1921 r., ł. 39; spr. sten. z 263. posiedzenia SU, 22 listopada 1921 r., 1. 30-31. Jedyny odnotowany w stenogramie SU przypadek odrzucenia rządowego projektu ustawy zdarzył się w lutym 1922 r. i spowodował podanie się do dymisji ministra robót publicznych G. Narutowicza; spr. sten. z 284. posiedzenia SU, 10 lutego 1922 r., 1. 13-14; „Kurier Polski” nr 42, 11 II 1922 r.

54 Spr. sten. z 39. posiedzenia SU, 16 maja 1919 r., 1. 9; spr. sten. z 50. posiedzenia SU, 14 czerwca 1919 r., ł. 4; spr. sten. z 74. posiedzenia SU, 21 lipca 1919 r., ł. 24. Precedensowym rozwiązaniem było również odesłanie przez marszałka projektu ustawy do komisji bez stawiania sprawy na forum plenarnym, na pisemny wniosek złożony w tej sprawie przez kluby reprezentujące większość izby; vide spr. sten. z 185. posiedzenia SU, 16 listopada 1920 r., 1. 65. Stosunkowo często marszałek wyznaczał komisję wiodąca, odpowiadającą za opracowanie sprawozdania o projekcie ustawy, i komisję, która miała współpracować z komisją wiodącą przy wykonaniu tego zadania.

55 Spr. sten. z 37. posiedzenia SU, 13 maja 1919 r., ł. 55. 
Treść debaty była też wskazówką dla prac komisji na następnym etapie procesu ustawodawczego ${ }^{56}$. Debata taka zajmowała niekiedy większą część posiedzenia plenarnego, z bardzo długimi, godzinnymi lub nawet dłuższymi mowami zainteresowanych posłów, którzy przemawiali w imieniu swoich klubów bądź własnym. Dla przykładu można tu przywołać całodzienną debatę z 10 stycznia 1922 r., podczas pierwszego czytaniu rządowego projektu ustawy o powszechnym obowiązku służby wojskowej ${ }^{57}$.

Skutkiem prawnym pierwszego czytania projektu ustawy na posiedzeniu plenarnym Sejmu było skierowanie go do komisji. Zgodnie z przepisami regulaminu dotyczącymi komisji (art. 49-53), komisje szczegółowo rozpatrywały przedłożenia i opracowywały referaty (sprawozdania o projekcie) ${ }^{58}$. Odtworzenie spójnego obrazu przebiegu tego etapu ustawodawczej procedury parlamentarnej w okresie prac konstytuanty napotyka na zasadnicze trudności, tak ze względu na pobieżność przepisów regulaminowych, jak i z uwagi na brak zachowanych źródeł sejmowych obrazujących etap postępowań komisyjnych. O jego przebiegu można więc wnioskować tylko na podstawie przekazów pośrednich. Wobec dyrektywy nakazującej stosowanie do obrad komisji odpowiednio regulaminu sejmowego (przepisów dotyczących obrad plenarnych, art. 51) należy zakładać, że etap prac komisyjnych w ramach postępowania ustawodawczego (przypadający między pierwszym a drugim czytaniem projektu ustawy na posiedzeniu plenarnym) składał się z następującego ciągu czynności:

- wpłynięcie projektu ustawy do komisji i wyznaczenie daty jego pierwszego czytania w komisji;

- pierwsze czytanie, czyli prezentacja projektu, ustalenie właściwości komisji, wybór referenta/ów (sprawozdawcy/ów) projektu, opracowanie referatu przez sprawozdawcę i wyznaczenie daty drugiego czytania w komisji;

- drugie czytanie, czyli debata ogólna i szczegółowa nad projektem, przegłosowanie poprawek, ewentualna praca sprawozdawcy nad zintegrowaniem poprawek $\mathrm{z}$ wersją pierwotną projektu; trzecie czytanie projektu w komisji;

- opracowanie sprawozdania komisji dla Sejmu przez referenta i przekazanie go marszałkowi izby ${ }^{59}$.

56 Ibidem.

57 „Kurier Polski” nr 11, 11 I 1922.

${ }^{58}$ Ibidem.

59 Komisja była zatem „niejako parlamentem w miniaturze”; vide Z. Cybichowski, op. cit., s. 108. W kontekście instytucji sprawozdawcy komisji warto również zaznaczyć, że w przypadkach kontrowersyjnych projektów ustaw w komisjach powoływano też — razem z referentem — koreferenta projektu, reprezentującego inny niż sprawozdawca większości komisji klub poselski, który — jak się wydaje — pełnił na etapie drugiego czytania projektu na forum plenarnym rolę rzecznika mniejszości komisji. W przypadku projektów obszernych istniała też praktyka wyłaniania przez komisję kilku referentów (sprawozdawców), przy czym jeden z nich był koordynatorem całości projektu, a pozostali odpowiadali za poszczególne części projektu. Praktyka funkcjonowania instytucji sprawozdawcy komisyjnego w Sejmie II RP wskazuje ponadto, że najczęściej poseł pełniący tę funkcję na etapie prac komisyjnych kontynuował swą rolę jako referent projektu ustawy w imieniu komisji na posiedzeniu plenarnym izby w trakcie drugiego czytania oraz w ewentualnej dodatkowej fazie prac komisyjnych między drugim a trzecim czytaniem. Referent był związany wynikiem debaty komisyjnej i stanowiskiem większości komisji, które powinien — przedstawiając sprawozdanie — prezentować lojalnie, obiektywnie i bezstronnie na posiedzeniu plenarnym, nawet wbrew swoim osobistym poglądom. 
W przypadku obrad komisji sejmowej kworum wynosiło połowę składu członkowskiego, a uchwały zapadały zwykłą większością głosów (art. 51 regulaminu). Poza członkami komisji w jej obradach mogli brać udział — jednak bez prawa głosu — posłowie niewchodzący w jej skład, a ponadto marszałek lub wyznaczony przez niego zastępca oraz przedstawiciele rządu, ale „bez prawa głosowania” (art. 52 regulaminu). W posiedzeniach komisji mogli również uczestniczyć wezwani przez nią posłowie niezasiadający w komisji, przedstawiciele rządu oraz rzeczoznawcy (art. 53 regulaminu), którzy mieli głos doradczy. Członkowie komisji na etapie prac komisji mogli wnosić poprawki i przedstawiać wnioski odnoszące się do całości projektu. Posłowie, w domyśle niebędący członkami komisji, mogli zgłaszać do marszałka Sejmu poprawki do projektu ustawy przesłanego do komisji. Marszałek „,ogłaszał” je wówczas „w Sejmie” i odsyłał do komisji (art. 42). W przepisach regulaminu nie określono terminu na opracowanie projektu ustawy w komisji, chyba że było to postępowanie skrócone ${ }^{60}$. Na zakończenie obowiązkiem komisji było przygotowanie drukowanego sprawozdania z prac nad projektem (art. 50 in fine regulaminu). Istotną częścią sprawozdania był wniosek komisji o odrzucenie lub przyjęcie projektu ustawy w „brzmieniu proponowanem” przez komisję (art. 40 ab initio regulaminu). Zatem w sprawozdaniu komisja mogła opowiedzieć się - i rekomendować to stanowisko Sejmowi — za odrzuceniem projektu ustawy w całości, przyjęciem go bez poprawek lub za przyjęciem go z poprawkami uchwalonymi przez komisję. Sprawozdanie musiało zostać posłom doręczone w druku najpóźniej w przeddzień drugiego czytania na forum plenarnym izby (art. 40 in medio regulaminu).

Na etapie prac komisyjnych nad projektem ustawy wykształciła się praktyka zwracania się komisji, do której skierowano projekt, do innej komisji o współpracę w jego opracowaniu. Zjawisko to, a w ślad za tym współdziałanie dwóch, a nawet trzech komisji w dziele opracowywania projektu ustawy było stosunkowo częste ${ }^{61}$. Niekiedy współdziałające komisje powoływały wspólne podkomisje, innym razem zbierały się na wspólne posiedzenia, najczęściej jednak przywołana do współdziałania komisja przedstawiała tylko swoją opinię komisji wiodącej ${ }^{62}$. Zdarzało się również, że już na posiedzeniu plenarnym marszałek, informując o skierowaniu projektu ustawy po pierw-

Przyjęło się również, że sprawozdawca był rzecznikiem rządowego projektu ustawy i jego obrońcą przed atakami ze strony opozycji ; vide m.in.: spr. sten. z 9. posiedzenia SU, 28 lutego 1919 r., ł. 357; spr. sten. z 173. posiedzenia SU, 15 października 1920 r., 1. 43; spr. sten. z 242. posiedzenia SU, 8 lipca 1921 r., 1. 64 i 66; spr. sten. z 285. posiedzenia SU, 14 lutego 1922 r., ł. 4-5, 21; „Kurier Polski” nr 87, 11 IV 1919; nr 284, 16 X 1920; M. Rataj, Wskazania obywatelskie i polityczne, Warszawa 1987, s. 159 i 207.

${ }^{60}$ Inaczej było w III Republice Francuskiej, gdzie w maju 1920 r. do regulaminów izb parlamentarnych wprowadzono przepis ograniczający ten czas do czterech miesięcy „,w celu zwalczenia jednej z najbardziej dokuczliwych plag francuskiego parlamentaryzmu, tzn. przetrzymywania projektów w komisjach"; vide B. Radziewanowska, Ewolucja francuskiego systemu komisji parlamentarnych na tle porównawczym, s. 43, praca doktorska: Wydział Prawa i Administracji UJ, sygn. 81/71, Archiwum Biblioteki Jagiellońskiej w Krakowie.

${ }^{61}$ Confer L. Zieleniewski, Regulamin Senatu na tle regulaminów oraz praktyki izb ustawodawczych w Polsce i innych państwach, t. II, Warszawa 1933, s. 18-21; „Kurier Polski” nr 27, 27 I 1922.

${ }^{62}$ „Kurier Polski” nr 133, 29 V 1919; nr 148, 4 VI 1921; nr 181, 7 VII 1921; nr 322, 26 XI 1921; nr 339, 13 XII 1921; R. Wojdaliński, Relacje posła na Sejm Ustawodawczy (1919-1922), t. I, s. 186, 196, 1999; t. II, s. 47, 52, maszynopis w Bibliotece Zakładu Narodowego im. Ossolińskich we Wrocławiu [dalej: Ossolineum], sygn. 14108/II; A. Wierzbicki, Wspomnienia i dokumenty (1877-1920), Warszawa 1957, s. 434-435. 
szym czytaniu do komisji, sugerował zajęcie się projektem przez dwie komisje i pozostawiał im według „,dotychczasowego zwyczaju” swobodę w jego rozpatrzeniu ${ }^{63}$. Osobliwym zjawiskiem było współdziałanie Komisji Konstytucyjnej z Konwentem Seniorów, który w maju 1922 r., w czasie prac nad ordynacją wyborczą do Sejmu wspomagał ją w uzgadnianiu szczegółowych rozwiązań projektu ${ }^{64}$. Precedensem było postępowanie na 223. posiedzeniu w dniu 14 kwietnia $1921 \mathrm{r}$. w sprawie zgody na ratyfikację traktatu ryskiego. Procedura pierwszego czytania stosownego projektu ustawy rozpoczęła się od wystapienia premiera Wincentego Witosa, następnie od razu, bez dyskusji, przystapiono do drugiego czytania. W imieniu Komisji Spraw Zagranicznych wygłosił uprzednio przygotowane sprawozdanie poseł Władysław Kiernik, po czym wywiązała się obszerna dyskusja, zakończona głosowaniem projektu ustawy w drugim i — niezwłocznie po nim — trzecim czytaniu. Do ustawy wyrażającej zgodę na ratyfikację, krótkiej i formalnej, do której załącznikiem był sam traktat, nie można było zgłaszać poprawek, ponieważ oznaczałoby to jednostronne ingerowanie w treść umowy międzynarodowej. Ustawę taką można było zatem tylko przyjąć bądź odrzucić. W omawianym przypadku Sejm uchwalił wspomnianą ustawę tylko przy jednym głosie sprzeciwu $^{65}$. Osobliwością omawianego postępowania były nie tylko trzy czytania przeprowadzone jednego dnia, ale również uruchomienie prac komisji jeszcze przed pierwszym czytaniem projektu ustawy na forum plenarnym.

Efektem finalnym fazy prac komisyjnych nad projektem ustawy było, jak już wspomniano, sprawozdanie, którego załącznikiem był projekt ustawy. W II Rzeczypospolitej, tak jak w III Republice Francuskiej, na której się niewątpliwie wzorowano, projekt ustawy wychodzący z komisji miał formę nadaną mu przez komisję $e^{66}$. Ponadto godzi się podkreślić, że jeżeli Sejm skierował do komisji więcej niż jeden projekt ustawy dotyczący tej samej materii, autonomicznym uprawnieniem komisji było stworzenie z nich projektu zintegrowanego bądź odrzucenie projektów nieakceptowanych przez większość i wybranie jako podstawy dalszych prac tylko jednego z nich. Zatem rola komisji nie polegała tylko na wydaniu generalnej opinii dla Sejmu, rekomendującej projekt bądź rekomendacji tej odmawiającej, oraz na zaproponowaniu poprawek do projektu, lecz — co należy podkreślić — na uprawnieniu do eliminowania projektów, do dokonywania w tych projektach zmian i nadawania im nowego, integralnego brzmienia, zgodnego ze stanowiskiem większości danej komisji ${ }^{67}$. Przegłosowana mniejszość nie stała ze swymi propozycjami na całkiem straconej pozycji, ponieważ jej stanowisko było zazwyczaj opisane w sprawozdaniu komisji, co dawało szansę na

${ }^{63}$ Na przykład spr. sten. ze 159. posiedzenia SU, 6 lipca 1920 r., ł. 6.

${ }^{64}$ A. Wątor, Działalność Zwiqzku Ludowo-Narodowego w latach 1919-1922, Szczecin 1992, s. 81.

${ }^{65}$ Spr. sten. z 223. posiedzenia SU, 14 kwietnia 1921 r., ł. 10; R. Wojdaliński, op. cit., t. III, s. 47-48; ustawa z dnia 15 kwietnia 1921 r. o ratyfikacji Traktatu Pokoju miedzy Polską a Rosją i Ukrainą podpisanego w Rydze dnia 18 marca 1921 r., Dz.U. nr 49, poz. 299; Traktat Pokoju między Polską a Rosją i Ukrainą podpisany w Rydze dnia 18 marca 1921 r., Dz.U. nr 49, poz. 300.

${ }^{66}$ Confer J. Stembrowicz, Parlament V Republiki Francuskiej, Warszawa 1963, s. 139.

${ }^{67}$ Przykładów dokonywania przez komisje zmian w projektach ustaw są setki. Jako zupełnie pierwszy z rzędu można przywołać rządowy projekt ustawy o dzierżawie odłogów, rozpatrywany w 1920 r., poważnie zmieniony przez Komisję Rolną; vide R. Wojdaliński, op. cit., t. II, s. 48-49. 
dotarcie ze swymi racjami do wszystkich parlamentarzystów i podjęcie próby przekonania większości z nich. Stałą praktyką, podobnie jak we Francji, było też wybieranie przez mniejszość komisji własnego sprawozdawcy, który przemawiał na posiedzeniu plenarnym w trakcie drugiego czytania na początku debaty, tuż po wystapieniu sprawozdawcy większości. Jak zauważono w literaturze, „Był to jeden $\mathrm{z}$ wielu parlamentarnych zwyczajów tego okresu, praktykowanych w celu ochrony mniejszości i tendencji do zaznajomienia izby z możliwie najszerszym wachlarzem opinii”'68.

W praktyce parlamentarnej okresu konstytuanty komisje zasadniczo nie rekomendowały Sejmowi odrzucenia projektu ustawy, choć zdarzył się wyjątek ${ }^{69}$. Warto podkreślić, że jeżeli większość w komisji miała poważne zastrzeżenia lub negatywny stosunek do projektu, to zazwyczaj nie prowadziła nad nim prac, pozostawiając projekt niejako bez rozpatrzenia ${ }^{70}$ i pozwalając, aby wskutek upływu kadencji izby objęła go zasada dyskontynuacji. W SU z różnych powodów „utonęło” w komisjach aż 315 projektów ustaw ${ }^{71}$, czyli 27,7\% ogółu zgłoszonych.

Drugie czytanie projektu ustawy na posiedzeniu plenarnym Sejmu stanowiło kulminacyjny etap całego postępowania ustawodawczego. To wówczas w większości przypadków decydował się los projektu w ogóle oraz zasadniczy kształt merytoryczny przyszłej ustawy. Drugie czytanie, jak wynika z obserwacji praktyki parlamentarnej, pochłaniało gros czasu przeznaczonego na debaty plenarne i skupiało największą uwagę opinii publicznej. Pomyślne przebrnięcie projektu ustawy przez tę fazę procesu ustawodawczego praktycznie przesądzało o jej uchwaleniu.

Drugie czytanie projektu ustawy na forum plenarnym nie mogło — co do zasady — odbyć się tego samego dnia co pierwsze (art. 43 ab initio regulaminu) ${ }^{72}$. Na wniosek marszałka mogło być ono jednak przeprowadzone tego samego dnia co pierwsze, jeśli nie sprzeciwiło się temu co najmniej 10 posłów (art. $43 \mathrm{zd} .2$ regulaminu) ${ }^{73}$. Drugie czytanie obejmowało rozprawę nad szczegółami projektu ustawy (art. 38 in fine regulaminu $)^{74}$. Debatę w drugim czytaniu rozpoczynało sprawozdanie i kończący je

${ }^{68}$ B. Radziewanowska, op. cit., s. 19-20.

${ }^{69}$ Wiosną 1922 r. Komisja Prawnicza rekomendowała izbie odrzucenie jednego z rządowych projektów ustaw. Notabene Sejm nie przychylił się do tego wniosku; vide spr. sten. z 301. posiedzenia SU, 28 kwietnia 1922 r., 1. 3.

70 Tak było na przykład z rządowym projektem ustawy o samorządzie gminnym, który był zwalczany przez posłów chłopskich z dawnej Galicji oraz byłego zaboru pruskiego za lansowanie koncepcji gminy zbiorowej; vide J. Sudoł, Wspomnienia z lat 1882-1945, t. V, s. 85, maszynopis Ossolineum, sygn. 15329/I, II.

71 Skorowidz, s. 478-479.

${ }^{72} \mathrm{~W}$ pierwotnym brzmieniu regulaminu nie mogło ono ,być zwyczajnie przedsięwzięte tego samego dnia co pierwsze", a po nowelizacji art. 43 z 24 marca 1920 r. nie mogło się odbyć ,z reguły” tego samego dnia, co pierwsze. Decyzję o wyznaczeniu daty drugiego czytania podejmował Konwent Seniorów.

${ }^{73}$ Było to oczywiście możliwe w odniesieniu do projektów ustaw nieodsyłanych do komisji lub takich, nad którymi komisja (prowadząc obrady równolegle do posiedzenia plenarnego, co było wyjątkowo dopuszczane przez marszałka; vide np.: spr. sten. z 49. posiedzenia SU, 13 czerwca 1919 r., ł. 2; spr. sten. z 205. posiedzenia SU, 3 lutego 1921 r., ł. 56-58; „Kurier Polski” nr 312, 16 XI 1921) zakończyła prace przed zamknięciem posiedzenia plenarnego.

${ }^{74}$ Z. Cybichowski, op. cit., s. 108. W projekcie regulaminu SU zgłoszonym przez ZLN zakładano, że w drugim czytaniu, przy dyskusji nad pierwszym artykułem, miały być dopuszczalne ,,wywody ogólne, całości ustawy dotyczące" (art. 52). 
wniosek komisji, przedstawiane przez posła sprawozdawcę/referenta (art. 19 ab initio regulaminu $)^{75}$. Z powodu luki w regulaminie w praktyce - o ile mniejszość komisji zawarła w sprawozdaniu swoje stanowisko - marszałek zaraz po referencie większości udzielał również głosu posłowi, który był sprawozdawcą wniosków mniejszości. Sprawozdawca mniejszości korzystał z dwóch przywilejów przewidzianych dla referenta większości: nieograniczonego czasu na wystapienie oraz prawa zabrania głosu na końcu debaty, ale przed wystapieniem referenta większości komisji ${ }^{76}$. Przed dopuszczeniem do głosu posłów z sali zdarzały się też wystapienia przedstawicieli rządu (zazwyczaj przy rozważaniu rządowych projektów ustaw), którzy na podstawie normy regulaminowej również mieli nieograniczony czas na wystapienie. Brak przedstawiciela rządu na sali był wystarczającym powodem do zdjęcia danego punktu z porządku obrad i przełożenia go na inny termin ${ }^{77}$.

Po wystapieniach sprawozdawcy (sprawozdawców) oraz ewentualnie przedstawiciela rządu ${ }^{78}$ rozpoczynała się seria wystąpień poselskich. Posłowie chcący zabrać głos w debacie powinni to zgłosić sekretarzowi obrad prowadzącemu listę mówców z równoczesnym oświadczeniem, czy będą przemawiać „za” czy „przeciw” projektowi, przy czym każdy wnoszący poprawkę był uważany za przemawiającego przeciw wnioskowi głównemu (art. 17 regulaminu). Po wystapieniu sprawozdawcy komisji marszałek był zobowiązany zarządzić odczytanie listy mówców w podziale na deklarujących się ,za" i ,przeciw” (art. 18 zd. 1 regulaminu), ale tego nie praktykowano. Ponadto marszałek kolejno udzielał głosu osobom zapisanym do dyskusji, zaczynając od deklarujących się ,przeciw” wnioskowi (art. 19 ab initio regulaminu). W czasie drugiego czytania posłowie niebędący członkami komisji, która opracowywała projekt, a także posłowie należący do mniejszości komisji lub pojedynczy posłowie mogli zgłaszać wnioski odnoszące się do projektu oraz szczegółowe popraw-

75 W przypadku nieobecności sprawozdawcy komisji na sali obrad, co było dosyć częstym zjawiskiem, wobec braku reguły regulaminowej marszałek — zgodnie z utartą praktyką — wzywał do złożenia sprawozdania w zastępstwie nieobecnego przez przewodniczącego komisji lub w drugiej kolejności jej wiceprzewodniczącego, sekretarza albo też wyznaczonego przez przewodniczącego innego członka komisji, która rozpatrywała projekt ustawy; np. spr. sten z 45. posiedzenia SU, 4 czerwca 1919 r., ł. 10; spr. sten. ze 127. posiedzenia SU, 5 marca 1920 r., ł. 44; spr. sten. z 238. posiedzenia SU, 23 czerwca 1921 r., ł. 46. Zdarzył się nawet odosobniony przypadek, że jeden z projektów referował w takiej sytuacji sprawozdawca mniejszości komisji; vide spr. sten. z 32. posiedzenia SU, 2 maja 1919 r., ł. 4-6 i 16-17. Gdy zastapienie sprawozdawcy nie było możliwe, marszałek przesuwał w czasie bądź zdejmował dany punkt z porządku dziennego obrad; vide spr. sten. ze 127. posiedzenia SU, 5 marca 1920 r., 1. 21; spr. sten. z 202. posiedzenia SU, 25 stycznia 1921 r., ł. 61; spr. sten. z 281. posiedzenia SU, 27 stycznia 1922 r., 1. 15.

${ }^{76}$ Confer L. Zieleniewski, Regulamin Senatu..., t. II, s. 57; spr. sten. z 38. posiedzenia SU, 15 maja 1919 r., ł. 12; spr. sten. z 41. posiedzenia SU, 23 maja 1919 r., ł. 75-78; spr. sten. ze 103. posiedzenia SU, 25 października 1919 r., ł. 31 i 36.

77 Vide np. spr. sten. z 91. posiedzenia SU, 24 października 1919 r., ł. 4.

78 Jeśli przedstawiciel rządu zabrał głos w debacie w trakcie czytania (przedstawicielom rządu, na podstawie przepisu art. 22 regulaminu, przysługiwało prawo wystapień poza kolejnościa), norma prawa zwyczajowego nakazywała rozpoczynanie debaty od początku (z otwieraniem listy mówców od nowa); vide spr. sten. z 30. posiedzenia SU, 11 kwietnia 1919 r., ł. 63; spr. sten. z 71. posiedzenia SU, 17 czerwca 1919 r., 1. 34; spr. sten. ze 127. posiedzenia SU, 5 marca 1920 r., 1. 26-27. Za przedstawiciela rządu uważano również zasiadającego w Sejmie w ławach rządowych prezesa Najwyższej Izby Kontroli Państwa. 
ki do poszczególnych artykułów ${ }^{79}$. Poprawki miały być składane „w ten sam sposób, co i wnioski samodzielne" (art. 26 zd. 1 w zw. z art. 15-16 regulaminu), a więc na piśmie i podpisane przez co najmniej 15 posłów. Poprawki, zgodnie z art. 27 regulaminu, mogły mieć jedynie formę wniosku o: „wykreślenie”, „dopisanie” lub „Zastąpienie określonych wyrazów". Debatę drugiego czytania, w którym zabierali głos posłowie zgłaszający się do dyskusji, kończyło wystąpienie referenta komisji, który miał ponadto przywilej zabierania głosu po każdej ze zgłoszonych poprawek ${ }^{80}$. Następnie marszałek ogłaszał przystapienie do głosowania, co oznaczało, że od tego momentu ,już nikomu głos do rozpraw nad przedmiotem udzielony być nie może" (art. 19 zd. 2 i art. 28 regulaminu) ${ }^{81}$.

Zgodnie z przywołaną już normą regulaminową (art. 38), drugie czytanie projektu ustawy na posiedzeniu plenarnym polegało na przeprowadzeniu debaty szczegółowej. Praktyka w tym względzie była jednak od początku obrad konstytuanty wyraźnie contra legem, ponieważ przy omawianiu art. 1 projektu ustawy wykształcił się zwyczaj przeprowadzania debaty ogólnej przed dyskusją szczegółową ${ }^{82}$. Przesłanką jego pojawienia się było prawdopodobnie nieprecyzyjne sformułowanie cytowanego wcześniej przepisu art. $40 \mathrm{zd}$. 1 regulaminu, ale też lansowanie przez marszałka izby sto-

${ }^{79} \mathrm{~W}$ konstytuancie funkcjonował zwyczaj niepowtarzania w debacie na forum plenarnym treści przemówień wygłoszonych uprzednio w komisji; vide spr. sten. ze 110. posiedzenia SU, 14 stycznia 1920 r., 1. $42-43$.

${ }^{80}$ Należy również zaznaczyć, że izba mogła w każdym stadium drugiego czytania, czyli przed ostatecznym przegłosowaniem projektu ustawy, uchwalić — zgodnie z art. 30 regulaminu — wniosek formalny o odesłanie go na powrót do komisji (wniosek taki miał pierwszeństwo przed innymi i był zazwyczaj niezwłocznie poddawany pod głosowanie przez marszałka), co oznaczało przerwanie i odroczenie drugiego czytania w oczekiwaniu na wynik uzupełniających prac (uzgodnień) komisji. Na posiedzeniu plenarnym można było też przyjąć inny wniosek formalny: o zamknięcie dyskusji, o przerwanie dyskusji (rozprawy), o odroczenie dyskusji, o głosowanie bez dyskusji, o głosowanie w całości (en bloc) i o skrócenie postępowania formalnego (a więc o zastosowanie trybu skróconego); vide Skorowidz, s. XXXVII. Najczęściej uchwalano wnioski formalne o przerwanie dyskusji. Po ich przegłosowaniu marszałek udzielał głosu już tylko przedstawicielowi rządu, jeżeli procedowano projekt ustawy przedłożony przez gabinet, oraz w celu wygłoszenia „ostatniego słowa” sprawozdawcy komisyjnemu; vide spr. sten. z 43. posiedzenia SU, 30 maja 1919 r., 1. 57-59. W początkach obrad konstytuanty na plenum toczono zaciekłe spory o wykładnię przepisów regulaminu dotyczących zamykania debaty; vide np. spr. sten. z 10. posiedzenia SU, 5 marca 1919 r., ł. 426-433. Po roku, wobec ciagłych kontrowersji na ten temat, marszałek dopuścił możliwość składania przez zainteresowanych posłów i kluby oświadczeń przed poddaniem pod głosowanie wniosku o zamknięcie dyskusji; vide spr. sten. ze 142. posiedzenia SU, 29 kwietnia 1920 r., ł. 48.

${ }^{81}$ Regulamin zawierał również przepisy normujące szczegółowo przebieg debaty (w istocie w każdym z trzech czytań, jak i nad wnioskami niemającymi charakteru ustawodawczego), odnoszące się do: kolejności, czasu, wielokrotności i miejsca przemówień, a także odczytywania przemówień, które było zasadniczo zakazane. Wyjątki ustanowiono dla sprawozdawców komisyjnych, przedstawicieli rządu oraz — za zgodą marszałka - odczytujących „,dokumenty lub akty, na których [poseł — P.A.T.] wywód opiera” (art. 18, 20-26).

${ }^{82}$ Confer spr. sten. z 9. posiedzenia SU, 28 lutego 1919 r., ł. 354; spr. sten. z 11. posiedzenia SU, 7 marca 1919 r., ł. 476. Na dowód istnienia omawianego zwyczaju można przywołać następującą wypowiedź marszałka: „Dyskusja szczegółowa otwarta. Jesteśmy przy art. 1. Według jednak przyjętego zwyczaju podczas szczegółowej dyskusji nad art. 1 wolno ogólnie mówić i o innych artykułach"; vide spr. sten. ze 112. posiedzenia SU, 20 stycznia 1920 r., ł. Vide także spr. sten. z 278. posiedzenia SU, 17 stycznia 1922 r., 1. 46-47; spr. sten. z 300. posiedzenia SU, 27 kwietnia 1922 r., 1. 15-16. Omawiany zwyczaj był zatem wyraźnie zbieżny z odnośną normą nieuchwalonego projektu regulaminu sejmowego autorstwa klubu ZLN. 
sownego wzorca niemieckiego. Zatem debatowanie nad odrzuceniem lub przyjęciem ustawy było siłą rzeczy rozważaniem zagadnienia ogólnego, a więc np. przydatności i celowości ustanowienia danej regulacji ustawowej. Zwyczaj ten wynikał więc z pragmatyzmu i z negatywnej weryfikacji nieżyciowego i nieodpowiadającego praktyce wskazanego przepisu regulaminu. Wolno również wysunąć przypuszczenie, że praktyka odbywania debaty ogólnej na początku drugiego czytania na posiedzeniu plenarnym mogła być podyktowana i tym, że w okresie konstytuanty wiele projektów ustaw (aż 222) było komisyjnymi inicjatywami ustawodawczymi, które po raz pierwszy pojawiały się na posiedzeniu plenarnym dopiero przy drugim czytaniu. Również zwyczaj nieprzeprowadzania w pierwszych latach działania SU debaty nad rządowymi projektami ustaw oraz zasada jej nieodbywania nad poselskimi nie dawały posłom niebędącym członkami komisji rozpatrującej projekt po pierwszym czytaniu okazji do wypowiedzi ogólnych odnoszących się do jego zasad i założeń legislacyjnych. Deficyt ten, spowodowany zarówno lukami regulaminowymi, jak i częstym pomijaniem debaty przy pierwszym czytaniu, musiał zatem zostać uzupełniony przez praktykę, która przybrała formę normy prawa zwyczajowego ${ }^{83}$.

Wynik drugiego czytania projektu ustawy na forum plenarnym Sejmu i jego ewentualne dalsze procedowanie uzależnione były od tego, czy do projektu zgłoszono poprawki, czy też nie. Jeżeli nie zgłoszono ${ }^{84}$, referent projektu lub inny poseł mogli zgłosić na podstawie art. 41 regulaminu wniosek o głosowanie nad projektem ustawy w całości (en bloc $)^{85}$. Wskutek zgłoszenia takiego wniosku projekt ustawy mógł zo-

${ }^{83}$ Uruchamianie debaty ogólnej nad zasadami projektu przy rozpatrywaniu art. 1 projektu ustawy $\mathrm{w}$ drugim czytaniu powodowało nie tylko skutek proceduralny $\mathrm{w}$ formie wydłużenia rozprawy, ale również inny, o doniosłym znaczeniu materialnoprawnym. Precedensowa sytuacja wytworzyła się w maju 1922 r., $\mathrm{w}$ trakcie procedowania na forum plenarnym projektu ustawy o monopolu spirytusowym. Otóż bez stosownego wniosku o odrzucenie nie uzyskał poparcia większości w trakcie głosowania w drugim czytaniu art. 1 projektu, który był osią całego projektu, ponieważ w nim ogólnie określono przedmiot regulacji ustawowej. Jak zanotował poseł A. Wierzbicki, „Zdawałoby się, że jest to jednoznaczne z odrzuceniem całej ustawy. Jednak marszałek Trąmpczyński (w myśl regulaminu Sejmu w sprawach dotyczących sposobu prowadzenia obrad, niewskazanych wyraźnie w regulaminie, marszałek Sejmu rozstrzygał ostatecznie), idąc na rękę rządowi, który oświadczył, że nie wycofuje ustawy, zdecydował inaczej. Powołał się na precedensy w parlamentach w Berlinie i Wiedniu, iż w drugim czytaniu wychodziły czasem ustawy z artykułami zupełnie sprzecznymi ze sobą i dopiero trzecie czytanie przesądzało sprawę ostatecznie. Poddał więc głosowaniu wszystkie artykuły po kolei, po czym w trzecim czytaniu poprawka posła Osieckiego o przywrócenie art. 1 została uchwalona 193 głosami przeciwko 186, a cała ustawa 185 głosami przeciwko 178”; A. Wierzbicki, Wspomnienia..., s. 353. Cytowany autor myli się, podając, że nie złożono wniosku o skreślenie art. 1 projektu ustawy. W istocie wniosek taki wpłynął i w głosowaniu nad nim głosy rozłożyły się po równo, 183 za i tyle samo przeciw; vide spr. sten. z 314. posiedzenia SU, 29 maja 1922 r., 1. 39-42; spr. sten. z 315. posiedzenia SU, 31 maja 1922 r., ł. 10-11; spr. sten. z 316. posiedzenia SU, 1 czerwca 1922 r., ł. 69.

${ }^{84}$ Przepis art. 41 regulaminu był niejasny, jeśli chodzi o niezgłoszeniu poprawek ,przed rozprawą nad drugim czytaniem". Tymczasem należy domniemywać, zresztą wykazała to praktyka, że poprawki zgłaszano właśnie w trakcie rozprawy. Formalnie oznaczało to, że poprawki powinny być wniesione na piśmie przed udzieleniem głosu pierwszemu z mówców zapisanemu na liście. Zatem wystapienia w rozprawie mogły dotyczyć: uzasadnienia zgłaszanych poprawek, polemiki ze zgłoszonymi poprawkami lub stawiania wniosków całościowych odnoszących się do projektu.

${ }^{85}$ Miało się to odbywać na stosowny wniosek porządkowy (formalny). W praktyce wniosek taki był zwyczajowo stawiany ex praesidio i przyjmowany przez izbę poprzez brak sprzeciwu (tacite). 
stać w wyniku głosowania całej izby uchwalony lub odrzucony. Odrzucenie projektu kończyło prace nad nim. Uchwalenie zaś projektu w całości otwierało możliwość dalszego biegu postępowania ustawodawczego, polegającego na przystapieniu do trzeciego czytania. Jeżeli w trakcie drugiego czytania projektu ustawy zgłoszono do niego na posiedzeniu plenarnym poprawki, marszałek zarządzał głosowanie. Przyjęcie poprawek oznaczało, że Sejm mógł ponownie odesłać projekt do tej samej komisji, która sprawozdawała (w przeważającej liczbie przypadków takiego odesłania) lub do innej, nawet specjalnej, powołanej ad hoc w tym celu (art. $40 \mathrm{zd}$. 3 regulaminu). Ponowne odesłanie projektu do komisji służyło uzgodnieniu poprawek, przyjętych $\mathrm{w}$ trakcie drugiego czytania, $\mathrm{z}$ innymi postanowieniami projektu ${ }^{86}$. Użycie w omawianym przepisie funktora „może” oznaczało fakultatywność tej czynności. Równie dobrze Sejm mógł się zachować przeciwnie i projektu po drugim czytaniu do komisji nie odsyłać. Jeżeli projekt w drugim czytaniu odesłano do komisji, to - wobec braku przepisów regulaminu na ten temat — należy domniemywać, że komisja przygotowywała (na piśmie) dodatkowe sprawozdanie o projekcie w związku poprawkami z przyjętymi na posiedzeniu plenarnym ${ }^{87}$. Można też przypuszczać, że musiało zostać ono dostarczone posłom w druku co najmniej w przeddzień trzeciego czytania. W regulaminie nie unormowano jednak również tej i następnych czynności do końca drugiego czytania, z wyjątkiem wspomnianej regulacji w art. 41. Zatem i w tym zakresie zawierał on istotną lukę prawną, którą starano się usunąć w praktyce parlamentarnej. Po dodatkowym sprawozdaniu komisji izba rozpoczynała głosowanie projektu od nowa. W dodatkowym sprawozdaniu komisja mogła wnioskować o przywrócenie artykułu skreślonego na posiedzeniu plenarnym w przerwanym drugim czytaniu projektu, przeciwko czemu protestowała jednak część posłów ${ }^{88}$.

Analiza stenogramów posiedzeń konstytuanty pozwala skonstatować, że głosowanie kończące fazę drugiego czytania projektu ustawy na forum plenarnym miało zasadniczo charakter szczegółowy. Przechodzono po kolei od artykułu do artykułu, odczytywano jego treść w wersji zaproponowanej przez komisję oraz odczytywano zgłoszone do niego poprawki. Następnie marszałek wzywał posłów, aby opowiedzieli się za lub przeciw poprawce bądź artykułowi ${ }^{89}$. Na końcu debatowano nad tytułem

${ }^{86}$ Z. Cybichowski, op. cit., s. 108.

${ }^{87} \mathrm{~W}$ art. 61 projektu regulaminu zgłoszonego przez ZLN zakładano przygotowanie przez komisję ponownego sprawozdania, które „,będzie stanowiło przedmiot powtórnego drugiego czytania”. Ponadto zgodnie z art. 63 tego projektu zakładano, że: „Marszałek może, jeśli uzna ustawę za niewłaściwie sformułowaną albo jeśli tak orzeknie izba, odesłać ją dla właściwego ostatecznego sformułowania do Komisji Prawniczej przed trzecim czytaniem".

88 Vide spr. sten. z 73. posiedzenia SU, 19 lipca 1919 r., ł. 8; spr. sten. z 75. posiedzenia SU, 22 lipca 1919 r., 1. 3-5, 7-9.

${ }^{89}$ Głosowanie szczegółowe przebiegało zazwyczaj według następującego schematu. Najpierw wniosek o wykreślenie całego artykułu (wniosek najdalej idący), przy czym istniał zwyczaj głosowania najpierw brzmienia artykułu w wersji przedstawionej przez komisję. Jeśli nie uzyskało ono większości, dopiero wówczas poddawano pod głosowanie wszystkie pozostałe poprawki zgłoszone do danego artykułu, począwszy od wniosku o jego wykreślenie (np. spr. sten. ze 183. posiedzenia SU, 10 listopada 1920 r., 1. 41; spr. sten. z 234. posiedzenia SU, 14 czerwca 1921 r., ł. 51-52). Ale bywało również na odwrót (vide np. spr. sten. z 206. posiedzenia SU, 4 lutego 1921 r., ł. 27). W drugiej kolejności Sejm przystępował do głosowania wnio- 
ustawy. W miarę nabywania doświadczeń, aby zaoszczędzić na czasie, rezygnowano z odczytywania artykułów w wersji proponowanej przez komisję, ponieważ posłowie znali ich treść z rozdawanych im druków ze sprawozdaniami. Jeżeli do artykułu nie zgłoszono żadnych poprawek, to przy braku sprzeciwów posłów marszałek traktował go jako przyjęty bez potrzeby przeprowadzania głosowania ${ }^{90}$. Po przegłosowaniu w opisany sposób wszystkich artykułów projektu ustawy marszałek zarządzał niekiedy głosowanie końcowe nad całym projektem ustawy. Nie było to jednak reguła.

Po uchwaleniu wszystkich przepisów projektu ustawy w drugim czytaniu Sejm głosował ewentualne rezolucje pod adresem rządu związane ze sposobem wykonania ustawy, zgłoszone przez komisję, mniejszość w komisji lub posłów na posiedzeniu plenarnym w trakcie tego czytania ${ }^{91}$.

Zgodnie z przepisem art. $40 \mathrm{zd}$. 3 regulaminu projekt ustawy po drugim czytaniu izba mogła odesłać ponownie do tej samej lub do innej komisji. Wobec braku wskazania w powołanym przepisie przesłanek ponownego odesłania, należy domniemywać, że mogło to nastapić w przypadku, jeśli w drugim czytaniu na forum plenarnym uchwalono poprawki do poszczególnych artykułów. Praktyka parlamentarna okresu konstytuanty dowodzi trafności tego domniemania i dostarcza na to stosunkowo wielu przykładów. Odesłanie następowało z wniosku marszałka ex praesidio, przy braku sprzeciwu ze strony posłów, albo uchwałą izby na wniosek zgłoszony z sali. Przyjęło się — w wykładni marszałka Sejmu — że prawo do zgłoszenia wniosku o odesłanie projektu ustawy do komisji po drugim czytaniu nie przysługiwało rządowi ${ }^{22}$. Komisja była zobowiązana, na podstawie dyspozycji wydanej jej przez marszałka oraz przyjętej w tym zakresie praktyki (regulamin nie zawierał przepisów na ten temat) rozważyć, czy wobec przyjęcia w drugim czytaniu poprawek nie ma sprzeczności między poszczególnymi postanowieniami projektu ustawy oraz opracować odpowiednie wnioski. Komisja wobec ponownego skierowania do niej projektu ustawy przed trzecim czytaniem była zobowiązana przygotować dodatkowe sprawozdanie na posiedzenie plenarne. Sprawozdanie zazwyczaj było drukowane ${ }^{93} \mathrm{i}$ warunkowało przystapienie do trzeciego czytania projektu ustawy w Sejmie. W regulaminie nie ustanowiono terminu dla komisji na wywiązanie się z wymienionych obowiązków. Jeżeli się on pojawiał, to tylko jako wykonanie dyspozycji przepisu regulaminu, stanowiącego o możliwości skrócenia przez izbę postępowania ustawodawczego (art. 44).

Instytucja trzeciego czytania projektu ustawy na posiedzeniu plenarnym Sejmu podlegała najskromniejszej - w porównaniu z poprzedzającymi ją fazami postępowa-

sku o wykreślenie fragmentu artykułu, a następnie wniosku o dopisanie passusu w artykule oraz wniosku o dodanie całego nowego artykułu. W okresie działania konstytuanty zdarzało się, że głosowano nad poszczególnymi artykułami tuż po zakończeniu nad nimi dyskusji, co oznaczało przeplatanie dyskusji z głosowaniami. Praktykę tę następnie zarzucono, przeprowadzając głosowanie szczegółowe po zakończeniu debaty nad wszystkimi artykułami projektu.

90 Vide spr. sten. z 315. posiedzenia SU, 31 maja 1922 r., 1. 5.

${ }^{91} \mathrm{Na}$ temat rezolucji uchwalanych w trakcie postępowania ustawodawczego w II Rzeczypospolitej vide więcej P.A. Tusiński, Postępowanie..., s. 170 i 185-190.

92 Vide spr. sten. z 82. posiedzenia SU, 31 lipca 1919 r., ł. 83.

${ }^{93}$ Obowiązek przygotowania sprawozdania można wyinterpretować z przepisu art. 50 regulaminu. 
nia ustawodawczego - reglamentacji regulaminowej. Zgodnie z pierwotnym brzmieniem przepisu art. 43 in medio mogło być ono otwarte ,zaraz po drugim”. Należy domniemywać, że mogło to nastapić, tylko jeśli nie odesłano projektu do komisji albo kiedy komisja przygotowała dodatkowe sprawozdanie jeszcze tego samego dnia. Użycie w przepisie funktora „może” oznaczało fakultatywność takiego rozwiązania. Równie dobrze trzecie czytanie projektu mogło być umieszczone w porządku dziennym jednego z następnych posiedzeń plenarnych izby. Konstytuanta po roku pracy, na wniosek Konwentu Seniorów, na 135. posiedzeniu plenarnym 24 marca 1920 r. ten przepis regulaminu jednak jednomyślnie zmieniła i sformułowała zasadniczy zakaz przeprowadzania drugiego i trzeciego czytania tego samego dnia ${ }^{94}$. Niezwłoczne przystapienie do trzeciego czytania po drugim było możliwe na zasadzie wyjątku, jeśli stosowny wniosek w tej sprawie poparło co najmniej 30 posłów. Zgodnie z art. 38 regulaminu trzecie czytanie projektu ustawy obejmowało rozprawę „nad całością” projektu ${ }^{95}$. W przepisie tym nie określono ani formy rozprawy na tym etapie postępowania ustawodawczego, ani tego, czym się ono miało kończyć. Oznaczało to, że do procedury trzeciego czytania stosowano przepisy ogólne dotyczące prowadzenia debaty i głosowań oraz reguły wypracowane w praktyce parlamentarnej. W głosowaniu zarówno poszczególne przepisy projektu, jak i jego całość mogły zostać uchwalone bądź odrzucone. Trzecie czytanie definitywnie kończyło procedowanie nad ustawą w Sejmie.

Jeżeli projekt ustawy został uchwalony w drugim czytaniu bez poprawek, co było zwyczajowo-prawną regułą $\mathrm{w}$ odniesieniu do ustaw wyrażających zgodę na ratyfikację umów międzynarodowych, to zgodnie z pierwotnym brzmieniem art. 43 regulaminu trzecie czytanie mogło nastapić ,zaraz po drugim”. W regulaminie nie sformułowano też zakazu niezwłocznego przystępowania do trzeciego czytania, gdy w drugim zostały uchwalone poprawki do projektu. Wniosek w sprawie niezwłocznego przystapienia do trzeciego czytania zgłaszał z reguły sprawozdawca komisji, ale zdarzało się również, że czynił to dowolny poseł ,z sali” lub nawet ex praesidio marszałek, oznajmiając o przystapieniu do tego czytania i zwracając się do posłów z pytaniem, kto jest przeciw. Pytanie o sprzeciw padało często, ale nie zawsze, nawet jeśli wniosek zgło-

94 „Marszałek [...] Jeżeli trzecie czytanie nie ma być czczą formalnością to i co do tego regulamin powinien zawierać jakiś wyraźny przepis, a nie rzucać sprawy na fale przypadkowej większości, co może mieć nie tylko fatalne skutki dla poszczególnych ustaw, ale może być źródłem bardzo znacznych niesnasek w Sejmie"; vide spr. sten. ze 135. posiedzenia SU, 24 marca 1920 r., 1. 4. Vide też: R. Wojdaliński, op. cit., t. IV, s. 164. W intencji inicjatorów zmiana ta miała służyć przede wszystkim wydłużeniu tych postępowań ustawodawczych, w których Sejm uchwalił poprawki do projektu w drugim czytaniu. Znowelizowany przepis zaowocował częściowo pożądaną praktyka, ponieważ okazało się, że stosunkowo często znajdowała się odtąd wymagana grupa co najmniej 30 posłów, którzy skutecznie mogli powodować odroczenie trzeciego czytania (przegłosowanie ich przez większość nie wchodziło przy takim sformułowaniu omawianego przepisu w rachubę). Niezależnie od słusznych intencji, klauzula ta była wykorzystywana często przez opozycję w celach obstrukcyjnych.

95 Z. Cybichowski zauważył, że w trzecim czytaniu ,dopuszczalne powinny być tylko poprawki stylistyczne, co jest zasadą w Anglii. Trzecie czytanie powinno być formalne; otworzenie obrad merytorycznych może wywołać skutki szkodliwe, gdy np. w ostatniej chwili przechodzi poprawka, która jest sprzeczna z podstawami ustawy. Mimo to wiele parlamentów pozwala na zgłaszanie w trzecim czytaniu poprawek merytorycznych"; vide Z. Cybichowski, op. cit., s. 108. 
sił inny poseł niż marszałek. Jeżeli sprzeciwu nie było, rozpoczynano procedurę trzeciego czytania. Działanie to mogło być nawet czysto symboliczne i sprowadzać się do wypowiedzenia przez marszałka dwu-, trzyzdaniowej formuły, która zarazem otwierała i kończyła trzecie czytanie ${ }^{96}$. Ze stenogramów z pierwszego roku funkcjonowania SU wynika, że izba - mimo formalnego istnienia instytucji trzech czytań — znakomitą większość ustaw faktycznie uchwalała w dwóch czytaniach. Praktyka była bowiem taka, że tuż po drugim czytaniu, o ile nie zgłoszono i nie przyjęto wniosku o odesłanie projektu ustawy z powrotem do komisji ${ }^{97}$, wniosek o rozpoczęcie trzeciego padał prawie zawsze i był milcząco akceptowany. Działo się tak dlatego, że w Sejmie — i nie tylko - wywierano swoistą presję, jeśli chodzi o szybkie stanowienie prawa wobec różnorakich problemów, przed jakimi stało odbudowujące się państwo polskie i które musiały być rozwiązywane niemal niezwłocznie ${ }^{98}$. Zatem trzecie czytanie sprowadzano najczęściej do podjęcia niezwłocznej uchwały o przegłosowaniu całego projektu. Przy czym uchwała ta bardzo często była przyjmowana tacite, bez przeprowadzania formalnego głosowania99. Czynność ta nie tylko kończyła szybkie i traktowane czysto formalnie trzecie czytanie, ale również całe postępowanie ustawodawcze w izbie. Do ogłoszenia drukiem ustawy brakowało jeszcze tylko podpisu marszałka

${ }^{9}$ Można przytoczyć np. jedną z wypowiedzi marszałka z początków 1920 r.: „Proponuję przystapić do 3 czytania. Nikt nie protestuje, głosu nikt nie żąda. Mogę przypuścić na mocy poprzedniego głosowania, że ustawa i w trzecim czytaniu jest przyjęta. Nie słyszę protestu”; vide spr. sten. ze 122. posiedzenia SU, 20 lutego 1920 r., 1. 24.

${ }^{97}$ Jeżeli projekt z powrotem odesłano do komisji, to przygotowywała ona dodatkowe, drukowane sprawozdanie, które przed trzecim czytaniem rozdawano posłom. Bywało jednak i tak, że formalnie nie odsyłano projektu ustawy do komisji, a mimo to do trzeciego czytania nie dochodziło niezwłocznie. Co ciekawe, odkładano trzecie czytanie nawet wówczas, gdy w drugim Sejm nie uchwalił do projektu żadnych poprawek. Rozwiązanie to znalazło następnie potwierdzenie w decyzji Konwentu Seniorów, który w lipcu 1919 r. postanowił, że sporne projekty ustaw (we wszystkich czytaniach) nie będą rozważane na posiedzeniach przypadających w poniedziałki i soboty, kiedy w izbie była obniżona frekwencja ze względu na wyjazdy posłów do domów; vide spr. sten. z 72. posiedzenia SU, 18 lipca 1919 r., 1. 85-86; spr. sten. z 73. posiedzenia SU, 19 lipca 1919 r., ł. 10.

98 Niezmiernie ciekawa była w tym względzie — i wielce problematyczna w kontekście zasady praworządności — sytuacja z początku lutego 1921 r. Otóż 4 lutego Sejm przyjął w drugim czytaniu projekt ustawy o ustanowieniu orderu Orła Białego. Rząd, jako inicjator ustawy, oraz popierający go w izbie posłowie liczyli na niezwłoczne trzecie czytanie projektu tego samego dnia. Tymczasem poseł H. Diamand, poparty przez więcej niż 30 posłów, sprzeciwił się temu i trzecie czytanie odłożono. Sprawa była jednak pilna, ponieważ ordery już wybito i 5 lutego — mimo nieuchwalenia ustawy w trzecim czytaniu — dwa z nich zostały wręczone w czasie wizyty J. Piłsudskiego we Francji prezydentowi A. Millerandowi oraz ministrowi L. Barthou. Ustawa została ostatecznie uchwalona przez Sejm dopiero kilka dni później, ale została antydatowana na 4 lutego 1921 r., a opublikowano ją dopiero 15 marca 1921 r., Dz.U. nr 24, poz. 136; vide „Kurier Polski” nr 35, 37-38, II 1921 r.

99 Jako ilustrację takiej uproszczonej i przyspieszonej procedury można przytoczyć następujący cytat ze stenogramu posiedzenia Sejmu: „Marszałek: [...] Proszę tych posłów, którzy są za przyjęciem projektu ustawy $[. .$.$] aby powstali z miejsc. (Większość). Ustawa jest przyjęta w drugim czytaniu. (P. Steinhaus [po-$ seł sprawozdawca — P.A.T]: Proszę o przystapienie do trzeciego czytania). Referent stawia wniosek o trzecie czytanie. Nikt nie protestuje, a ponieważ była tak znaczna większość przy głosowaniu w drugim czytaniu, zatem i teraz mogę przyjąć, że i w trzecim czytaniu, o ile nie usłyszę protestu, ustawa jest przyjęta. Nie ma protestu, zatem ustawa przyjęta i w trzecim czytaniu"; vide spr. sten. z 56. posiedzenia SU, 26 czerwca 1919 r., 1. 8. 
Sejmu. Stan taki powodował, że ustawy uchwalane „na gorąco”, niezwłocznie po drugim czytaniu, miały wiele wad wewnętrznych, zarówno w formie luk (po wykreśleniach), sprzeczności i niespójności (wskutek przyjętych poprawek), jak i sformułowań, które odbiegały od wymogów poprawnej techniki legislacyjnej i spójności systemowej. Uproszczenie procedury trzeciego czytania nie było stosowane konsekwentnie, bywało bowiem również i tak, że marszałek przeprowadzał formalne głosowanie w trzecim czytaniu, wzywając posłów do powstania z miejsc w celu wyrażenia poparcia dla uchwalanego projektu ustawy ${ }^{100}$. Wspomniana częściowa zmiana procedury trzeciego czytania - mimo jej pewnych pozytywnych rezultatów — nie wpłynęła zasadniczo na spowolnienie tempa procedowania ustaw w dalszym okresie funkcjonowania konstytuanty.

Zatem w SU trzecie czytanie bardzo często sprowadzało się tylko do milczącego powtórzenia wyniku głosowania z drugiego czytania. Niemniej jednak konstytuanta prowadziła również relatywnie wiele postępowań ustawodawczych, które dostarczają przykładów rozbudowanego przebiegu procedury trzeciego czytania. Jak zaznaczono wcześniej, zgodnie z regulaminem i początkową praktyką trzecie czytanie miało obejmować dyskusję ogólną nad całością ustawy. Stosunkowo szybko zaczęto jednak od tej formuły odchodzić i zmierzać do modelu charakterystycznego dla drugiego czytania, ponieważ trzecie czytanie, o ile otwierano w nim debatę, zaczęło obejmować nie tylko dyskusję ogólna, lecz koncentrować się na rozprawie szczegółowej, ze zgłaszaniem i uchwalaniem poprawek do poszczególnych artykułów projektu ustawy. Już w początkach funkcjonowania konstytuanty - wbrew przepisom regulaminu i rozwiązaniom przyjętym w parlamencie wiedeńskim oraz galicyjskim Sejmie Krajowym, przełamując opór części posłów, a za wzorem Reichstagu i pruskiego Landtagu (z wyraźnym poparciem marszałka Wojciecha Trąmpczyńskiego) - zaczęto dopuszczać możliwość wnoszenia w trzecim czytaniu nie tylko poprawek stylistycznych, ale także merytorycznych, nawet tych, które zostały odrzucone w drugim czytaniu ${ }^{101}$. Zatem debata w trzecim czytaniu koncentrowała się na uzasadnianiu zgłaszanych poprawek. Poważne i ciągle powracające spory budziła również kwestia terminu zgłaszania poprawek do trzeciego czytania. Zasadniczo od początku zgadzano się z tym, że poprawki powinny być wydrukowane i rozdane posłom przed głosowaniem. Niemniej w praktyce część poprawek posłowie dostawali tuż przed posiedzeniem, na którym miało zostać przeprowadzone trzecie czytanie, część była rozdawana w powielonym maszynopisie już w trakcie posiedzenia, część już w trakcie trzeciego czytania, a część była zgłaszana nawet ustnie $\mathrm{w}$ trakcie debaty, tuż przed samym głosowaniem. Wynikający z tego chaos budził krytyczne uwagi wielu posłów i negatywnie wpływał na jakość stanowionego prawa. W tej sytuacji Konwent Seniorów postanowił w czerwcu 1921 r.,

100 Vide np.: spr. sten. z 295. posiedzenia SU, 31 marca 1922 r., 1. 31; spr. sten. z 296. posiedzenia SU, 4 kwietnia 1922 r., 1. 34; spr. sten. z 297. posiedzenia SU, 6 kwietnia 1922 r., 1. 53 i 60.

101 Vide spr. sten. z 32. posiedzenia SU, 2 maja 1919 r., ł. 47; spr. sten. z 76. posiedzenia SU, 24 lipca 1919 r., 1. 25; spr. sten. z 83. posiedzenia SU, 1 sierpnia 1919 r., 1. 113-118; spr. sten. ze 122. posiedzenia SU, 20 lutego 1920 r., ł. 5; spr. sten. z 328. posiedzenia SU, 18 lipca 1922 r., 1. 14-16. 
że poprawki do trzeciego czytania powinny być zgłaszane i rozdane posłom przed rozpoczęciem dyskusji (praktycznie za spełnienie tego wymogu uważano dostarczenie ich przynajmniej w jednym egzemplarzu samym tylko klubom parlamentarnym). Od tej pory starano się konsekwentnie trzymać tej zasady, a marszałek powoływał się nawet w tym względzie na ",prawo zwyczajowe"102.

Trzecie czytanie projektu ustawy zazwyczaj kończyło się formalnym głosowaniem. Najpierw głosowano poprawki, a następnie cały projekt ustawy ${ }^{103}$. Warto zauważyć, że niektórzy posłowie traktowali trzecie czytanie jako ostatnią szansę na wyeliminowanie projektu ustawy w całości. Jednak już latem 1919 r. w marszałek uznał wniosek formalny o przejście do porządku dziennego nad projektem ustawy, zgłoszony w trakcie trzeciego czytania, za niedopuszczalny i zauważył, że posłowie, którzy chcą głosować przeciw projektowi, mogą w kończącym trzecie czytanie głosowaniu en bloc opowiedzieć się przeciw niemu ${ }^{104}$. Pod koniec obrad konstytuanty pojawił się też praktyczny problem związany z dopuszczalnością reasumpcji głosowania nad uchwalonym już przez Sejm w głosowaniu szczegółowym artykułem projektu ustawy. W regulaminie brakowało przepisu na ten temat, natomiast w przywołanych przez marszałka regulaminach parlamentarnych innych państw dopuszczano reasumpcję tylko przy braku sprzeciwu. Rozstrzygnięcie tej precedensowej sytuacji pozostawiono izbie, która wypowiedziała się w głosowaniu przeciw dopuszczalności reasumpcji głosowania $\mathrm{w}$ trzecim czytaniu ${ }^{105}$.

Na koniec omawianego zagadnienia godzi się też zauważyć, że w okresie działania SU wykształciła się praktyka wieńczenia etapu trzeciego czytania niezwykle ważnych projektów ustaw okolicznościowym przemówieniem marszałka izby, w którym zazwyczaj podkreślał on rangę ustanowionego prawa i wyrażał podziękowania posłom i komisjom, które przyczyniły się do jego uchwalenia ${ }^{106}$.

Skrócona procedura postępowania ustawodawczego, przewidziana w przepisach art. 44 regulaminu, mogła być zastosowana na wniosek poparty przez co najmniej 15 posłów (w domniemaniu również na wniosek przedstawiciela rządu). W postępowaniu skróconym przewidziano:

- zwolnienie z obowiązku drukowania wniosku (projektu ustawy) lub sprawozdania komisji;

— dopuszczenie natychmiastowej rozprawy nad projektem bez odesłania go do komisji;

- dopuszczenie rozprawy zaraz po rozdaniu drukowanego sprawozdania komisji, co oznaczało przyspieszenie drugiego i trzeciego czytania, bez zachowania wymo-

102 Vide spr. sten. z 238. posiedzenia SU, 23 czerwca 1921 r., ł. 23-24; spr. sten. z 295. posiedzenia SU, 31 marca 1922 r., ł. 4 i 24; spr. sten. z 232. posiedzenia SU, 28 czerwca 1922 r., 1. 4; spr. sten. z 331. posiedzenia SU, 27 lipca 1922 r., ł. 17-20.

103 Vide spr. sten. z 84. posiedzenia SU, 2 sierpnia 1919 r., 1. 61-62; spr. sten. z 219. posiedzenia SU, 15 marca 1921 r., ł. 51-52.

104 Vide spr. sten. z 84. posiedzenia SU, 2 sierpnia 1919 r., 1. 60.

105 Vide spr. sten. z 332. posiedzenia SU, 28 lipca 1922 r., 1. 18-21.

106 Vide np. spr. sten. z 82. posiedzenia SU, 31 lipca1919 r., 1. 52-53. 
gu dotrzymania terminu jednego dnia na zapoznanie się posłów z drukiem sprawozdania komisji;

- wyznaczenie komisji terminu na przedłożenie sprawozdania. Wobec braku stosownego przepisu należy sądzić, że ten termin powinien zostać określony we wniosku o jego wyznaczenie.

\section{SZCZEGÓLNE POSTĘPOWANIA USTAWODAWCZE}

Zespół szczególnych procedur ustawodawczych stanowiły w praktyce funkcjonowania SU dwie procedury: konstytucyjna i budżetowa, a także mieszczące się formalnie w ramach funkcji kontrolnej parlamentu procedura postępowania w sprawach wyrażenia przez Sejm zgody na ratyfikację umowy międzynarodowej przez Naczelnika Państwa oraz procedura postępowania w sprawach zatwierdzania przez Sejm ustawodawstwa dekretowego.

Zgodnie z przepisem art. II ab initio małej konstytucji głównym zadaniem SU było przygotowanie i uchwalenie konstytucji. W tymczasowym regulaminie obrad nie przewidziano odrębnej procedury w zakresie prac nad projektem (projektami) konstytucji, stąd przepisy odnoszące się do ogólnego trybu prac nad wnioskami (w przypadku małej konstytucji) oraz ogólnego (zwykłego) trybu postępowania ustawodawczego (w przypadku konstytucji marcowej) musiały zostać — co rozstrzygnięto w praktyce parlamentarnej — zastosowane w pełnym zakresie do procedowania w sprawach wydawania aktów rangi ustrojowej. Tryby uchwalenia obydwu wymienionych ustaw zasadniczych przez konstytuantę, łącznie z komentarzem do przepisów stanowiących ich podstawę normatywna, zostały wyczerpująco przedstawione w literaturze przedmio$\mathrm{tu}^{107}$, co zwalnia autora niniejszego tekstu od ich ponownego podejmowania.

Drugie ze szczególnych postępowań ustawodawczych w latach prac konstytuanty, czyli procedura budżetowa, nie znajdowała żadnego umocowania w przepisach prawa pozytywnego, co oznaczało, że do jej biegu stosowały się przepisy ogólne normujące postępowanie ustawodawcze, uzupełniane stosownymi normami prawa zwyczajowego i doraźnie kształtowaną praktyką parlamentarną ${ }^{108}$. Już w okresie funkcjonowania konstytuanty wykształciła się norma prawa zwyczajowego ograniczająca krag podmiotów

107 Vide m.in.: S. Krukowski, Geneza konstytucji z 17 marca 1921 r., Warszawa 1977; idem, Konstytucja Rzeczypospolitej Polskiej z 1921 r., [w:] Konstytucje Polski. Studia monograficzne z dziejów polskiego konstytucjonalizmu, t. II, red. M. Kallas, Warszawa 1990, s. 19-70; W. Komarnicki, op. cit., s. 133-206; idem, Ustrój państwowy Polski współczesnej. Geneza i system, Wilno 1937, s. 30-34; A. Gwiżdż, Burżuazyjno-obszarnicza Konstytucja z 1921 roku w praktyce, Warszawa 1956, s. 47-72; A. Ajnenkiel, Spór o model parlamentaryzmu polskiego do roku 1926, Warszawa 1972, s. 207-241; M. Pietrzak, Tryb uchwalenia konstytucji marcowej (17 marca 1921 r.), [w:] Tryby uchwalania polskich konstytucji, red. M. Wyrzykowski, Warszawa 1998, s. 43-52; F. Siemieński, Uchwalanie konstytucji polskich, [w:] Przeobrażenia we współczesnym prawie konstytucyjnym, red. K. Działocha, „Acta Universitatis Wratislaviensis” 1995, Prawo CCXLVII; W.T. Kulesza, Uchwała Sejmu Ustawodawczego z dnia 20 lutego 1919 r. o powierzeniu Józefowi Pitsudskiemu dalszego sprawowania urzędu Naczelnika Państwa, „Przegląd Sejmowy” 2007, nr 5, s. 33-56; P.A. Tusiński, Postępowanie..., s. 355-375.

${ }^{108} \mathrm{Na}$ temat procedury budżetowej w Sejmie i Senacie okresu II RP vide szerzej P.A. Tusiński, Postępowanie..., s. 295-353. 
uprawnionych do inicjatywy budżetowej (w zakresie przedkładania stosownego projektu ustawy skarbowej wraz z załączonym preliminarzem budżetowym) wyłącznie do rządu. Norma zwyczajowa została następnie podniesiona do rangi prawnopozytywnej w konstytucji marcowej. Ograniczenie inicjatywy budżetowej tylko do rządu wynikało ze szczególnego charakteru budżetu, którego przygotowanie wymagało specjalistycznych zabiegów fachowych ${ }^{109}$. W latach 1919-1922 rząd złożył w Sejmie za pośrednictwem ministra skarbu sześć projektów ustaw skarbowych z załączonym preliminarzem budżetowym lub prowizorium budżetowym bądź wnioskiem o udzielenie dodatkowych kredytów. Pierwszy z projektów obejmował okres I półrocza 1919 r., dwa następne dotyczyły okresów 9-miesięcznych, a dwa ostatnie objęły okresy roczne lat 1921 i $1922^{110}$. W tym czasie Sejm trzykrotnie wzywał rząd - we wnioskach nagłych — do wniesienia projektu budżetu. Pierwszy raz w odniesieniu do projektu budżetu na rok 1921, którego przedłożenia izba zażyczyła sobie najpierw do dnia 15 czerwca, a gdy to nie nastąpiło, wezwała rząd „do jak najszybszego przedłożenia”, już bez wyznaczania konkretnego terminu ${ }^{111}$. W trzeciej rezolucji zażądano uzupełnienia projektu budżetu na rok 1922. Izba procedowała nad ustawami skarbowymi w trybie przyjętym dla uchwalania ustaw. Sejm tylko dwukrotnie przystapił do drugiego czytania przedłożonych projektów ustaw budżetowych (na podstawie sprawozdań przygotowanych przez Komisję Skarbowo-Budżetowa) na posiedzeniu plenarnym, ale ani razu ich nie ukończył i nie przystapił do trzeciego czytania. Tak więc SU w całym okresie swego funkcjonowania ani razu nie zdołał uchwalić budżetu państwa ${ }^{112}$.

Mieszczace się formalnie w ramach funkcji kontrolnej postępowanie w sprawie wyrażenia zgody Sejmu na ratyfikację umowy międzynarodowej toczyło się w okresie działania konstytuanty zasadniczo w ramach ogólnego postępowania ustawodawczego. Co najwyżej w takiej sytuacji relatywnie częściej niż w przypadku rozpatrywania projektów innych aktów sięgano do instrumentów postępowania skróconego ${ }^{113}$.

Szczególna procedura zatwierdzania przez konstytuantę ustawodawstwa dekretowego wykazywała w części zastosowań cechy typowego postępowania ustawodawczego, w innych zaś cechy standardowych zasad postępowania kontrolnego. Obydwa sposoby znajdowały umocowanie prawne w omówionych wcześniej aktach prawa pozytywnego, normach prawa zwyczajowego oraz praktyce parlamentarnej. Stosunek konstytuanty do ustawodawstwa dekretowego został opisany w literaturze przedmiotu $^{114}$, wobec czego nie wymaga ponownej eksplikacji. Spośród poczynionych

109 Vide szerzej: T. Grodyński, Zasady gospodarstwa budżetowego w Polsce na tle porównawczem, Kraków 1932, s. 229-230.

${ }^{110}$ T. Grodyński (op. cit., s. 30-32) wylicza tylko pięć projektów; Sejm Ustawodawczy RP, druki nr: 402, 692, 966, 2049, 2463, 3223.

111 Vide spr. sten. z 232. posiedzenia SU, 7 czerwca 1921 r., ł. 66-67; „Kurier Polski”, nr 182, 8 VII 1921.

112 Confer T. Grodyński, op. cit., s. 30-32.

113 Vide P.A. Tusiński, Postępowanie..., passim w obrębie rozdz. II (s. 85-202); M. Kijowski, Udział Sejmu i Senatu w ratyfikacji umów międzynarodowych (1919-2003), Rzeszów 2004, s. 41-57. Drugi z autorów nie zajmuje się jednak analizą i egzegezą aspektów prawno-proceduralnych postępowania ustawodawczego w zakresie uchwalania przez SU ustaw wyrażających zgodę na ratyfikację umów międzynarodowych.

114 Vide R. Kraczkowski, op. cit., s. 29-86; P.A. Tusiński, Postępowanie..., s. 259-266. 
w powołanych opracowaniach ustaleń należy przywołać tylko te, które sumarycznie obrazują to zagadnienie. Dyspozycja, jak określano to w SU, „konstytucyjnego zatwierdzenia" ustawodawstwa tymczasowego (dekretowego), delegowanego i wyjątkowego odnosiła się do dziewięciu dekretów Rady Regencyjnej, 210 dekretów zatwierdzonych przez Tymczasowego Naczelnika Państwa, 10 dekretów Rady Ministrów oraz 63 rozporządzeń ROP. Spośród dekretów Rady Regencyjnej konstytuancie przedstawiono na wspomnianym wcześniej 1. posiedzeniu siedem dekretów, ponieważ dwa utraciły aktualność. Z dekretów Naczelnika Państwa nie przedstawiono Sejmowi jednego (z 8 lutego 1919 r.) ${ }^{115}$, a jeden ze zgłoszonych został wycofany. Natomiast dekrety Rady Ministrów oraz rozporządzenia ROP przedstawiono izbie w całości.

We wspomnianych aktach konstytucyjnych Rady Regencyjnej z 15 października 1918 r. i Naczelnika Państwa z 22 listopada 1918 r., nakładających na rząd obowiązek - pod rygorem utraty mocy — przedstawienia SU na 1. posiedzeniu do zatwierdzenia nie wyznaczono Sejmowi terminów na rozpatrzenie i zatwierdzenie przedstawionych ustaw tymczasowych wydanych przed jego zebraniem się. Problemu tego nie podjęto również w małej konstytucji. W tej sytuacji może się wydawać, że kwestia ta, jak również szczegółowe określenie procedury rozpatrywania przedłożonych dekretów miały zostać unormowane w szczególnych przepisach tymczasowego regulaminu obrad. Niestety tak się nie stało i tryb postępowania w tym zakresie wynikał z norm określających ogólne postępowanie w sprawach wniosków i projektów ustaw oraz z praktyki parlamentarnej, która — co należy wyraźnie podkreślić — nie budziła w konstytuancie żadnych sporów natury proceduralnej. Odnośnie do samej kwestii tymczasowości obowiązywania ustawodawstwa dekretowego poprzedzającego zebranie się SU, godzi się zauważyć, że (wskutek enigmatyczności wspomnianych dekretów konstytucyjnych, na podstawie których je ustanowiono) nie było jasne, czy utrata mocy obowiązującej dekretów nieprzedstawionych do zatwierdzenia Sejmowi miała nastapić z mocy samego faktu braku przedłożenia (ex lege), czy też powinna zostać stwierdzona np. specjalną uchwałą konstatującą brak przedłożenia.

Wspomniano już, że dekrety ustawodawcze Rady Regencyjnej i Naczelnika Państwa zostały odesłane na 1. posiedzeniu konstytuanty do Komisji Prawniczej i innych komisji według ich właściwości resortowych. Działając w trybie ustawodawczym, komisje przygotowywały sprawozdania na posiedzenia plenarne Sejmu. Konkluzja takiego sprawozdania sprowadzała się do zaproponowania jednego z trzech wariantów możliwych rozwiązań: zatwierdzenia dekretu, wprowadzenia do niego zmian lub odrzucenia go w całości. Jak ustalił R. Kraczkowski, w odniesieniu do 24 dekretów wydanych przed 10 lutego 1919 r. komisje SU wniosły o ich zatwierdzenie, co izba przyjmowała w formie zwykłej uchwały, na ogół bez dyskusji, ale czasami opatrywała rezolucjami skierowanymi do rządu (a więc w trybie kontrolnym). W stosunku do 33 dekretów komisje wnioskowały o wprowadzenie do nich

115 Mimo że nie został opublikowany w „Dzienniku Praw”, obowiązywał kilka lat i został zastapiony dopiero ustawą uchwaloną przez Sejm. 
zmian, co zawsze odbywało się przez przygotowanie przez nie nowego kompleksowego projektu ustawy, łączącego pozostawiane w mocy przepisy dekretu oraz wprowadzane nowe regulacje (tak więc postępowanie nosiło wszelkie cechy postępowania ustawodawczego). Ustawa taka po uchwaleniu zastępowała dekret, bez względu na zakres proponowanych zmian. Na początku 1920 r. rozwiązanie to uważano w Sejmie za utarty zwyczaj wprowadzania zmian do dekretów ${ }^{116}$. Sprawozdanie komisji $\mathrm{z}$ wnioskiem o wprowadzenie do rozpatrywanego dekretu zmian, wraz z załączonym stosownym projektem ustawy, traktowano jako drugie czytanie projektu, ponieważ przedstawienie tytułu dekretu na pierwszym posiedzeniu izby było równoznaczne z pierwszym czytaniem projektu ustawy. Również w takich przypadkach rzadko dochodziło do debaty w trakcie drugiego czytania, a Sejm uchwalał stosowny projekt ustawy tylko po wystapieniu komisyjnego sprawozdawcy i zazwyczaj niezwłocznie w trzecim czytaniu. Komisje SU zgłosiły sześć wniosków o uchylenie dekretów w całości, z czego izba zdołała rozpatrzyć i zaaprobować tylko trzy. Uchylenie dekretu następowało poprzez uchwałę Sejmu opublikowaną w „Dzienniku Ustaw” (a więc również w trybie kontrolnym). W sumie więc SU w trybie przyjętym dla „konstytucyjnego zatwierdzania" dekretów, zdołał rozpatrzyć w pełni tylko 60 spośród 215 ostatecznie przedstawionych przez rząd do zatwierdzenia dekretów, czyli niespełna $28 \%$. Komisje zdołały przygotować sprawozdania jeszcze w sprawie kilku kolejnych dekretów, ale do ich rozpatrzenia na forum plenarnym nie doszło. Jak zauważył badacz problemu, rozpatrywanie przez konstytuantę dekretów wydanych przed 10 lutego 1919 r. praktycznie zakończyło się w styczniu 1920 r., ponieważ po tej dacie jeszcze tylko w grudniu tego roku stanęła na plenum sprawa jednego dekretu. Nieuchylone w całości bądź zmienione stosowną ustawą (formalnie nowelizującą dekret) akty ustawodawstwa tymczasowego sprzed 10 lutego 1919 r. obowiązywały zatem nadal, nierzadko jeszcze przez wiele następnych lat, po czym były sukcesywnie znoszone ustawami uchwalanymi przez parlament w zwykłym trybie ustawodawczym bądź derogowane po zamachu majowym rozporządzeniami Prezydenta RP z mocą ustawy.

W odniesieniu do ustawodawstwa delegowanego przez konstytuantę na Radę Ministrów w dwóch ustawach je ustanawiających określono termin — trzy miesiące na wydanie dekretów oraz przedstawienie ich izbie do zatwierdzenia. W tym trybie wpłynęło do Sejmu 10 dekretów, ale z analizy stenogramów posiedzeń plenarnych wynika, że utknęły one w komisjach i nie stały się przedmiotem stosownych sprawozdań na forum plenarnym. Ponadto — zgodnie z ustawą o ROP — wszystkie wydawane rozporządzenia i zarządzenia, które wymagały zatwierdzającej uchwały Sejmu, miały być mu przedkładane do zatwierdzenia za pośrednictwem premiera na najbliższym posiedzeniu (art. 4 ust. 2). W praktyce, aprobowanej przez doktrynę, tylko rozporządzenia ustanawiały normy ogólne, a więc miały charakter ustaw tymczasowych ${ }^{117}$. W całym okresie swojej działalności Rada Regencyjna wydała 63 rozpo-

116 Tak twierdził poseł M. Rataj; vide spr. sten. ze 109. posiedzenia SU, 13 stycznia 1920 r., 1. 5.

117 R. Kraczkowski, op. cit., s. 58-59. 
rządzenia, z czego sześciu nie opublikowano ${ }^{118}$. Rząd przekazał Sejmowi do zatwierdzenia 59 rozporządzeń, które trafiły do właściwych komisji w celu rozpatrzenia ${ }^{119}$. W odniesieniu do zatwierdzania rozporządzeń ROP Sejm przyjął zasadniczo tryb postępowania stosowany wcześniej do zatwierdzania dekretów wydawanych przed 10 lutego 1919 r. ${ }^{120}$ Jak ustalił R. Kraczkowski, przedmiotem sprawozdań komisji stało się tylko 10 rozporządzeń ROP, a więc niespełna $17 \%$ ze zgłoszonych izbie. Spośród nich konstytuanta na wniosek komisji zatwierdziła sześć, co nastapiło w formie uchwał Sejmu, ogłoszonych w „Monitorze Polskim” jako obwieszczenia marszałka izby (a więc w trybie kontrolnym). Jedno rozporządzenie Sejm zatwierdził ze zmiana, a więc ustawą uchwaloną 26 listopada 1920 r. Trzy rozporządzenia zostały zaś uchylone, przy czym jedno 29 października 1920 r. uchwałą Sejmu (w trybie kontrolnym), a dwa ustawami z 9 i 17 grudnia $1920 \mathrm{r}^{121} \mathrm{~W}$ porównaniu z procedurą stosowaną do zatwierdzania dekretów Rady Regencyjnej i Tymczasowego Naczelnika Państwa widać niekonsekwencję Sejmu w zakresie stosowanej formy prawnej uchylania rozporządzeń ROP. Niekonsekwencję tę cytowany autor próbuje wytłumaczyć twierdzeniem, że izba wypowiadała się w formie ustawy dopiero po ustaniu mandatu ROP, czyli najpóźniej z końcem listopada $1920 \mathrm{r}$. (co było raczej działaniem politycznym, ponieważ nigdy nie zostało potwierdzone formalnym aktem). Ustanie mandatu ROP i udzielenie jej absolutorium, choć znów nieformalne, było też — zdaniem R. Kraczkowskiego — sumarycznym zatwierdzeniem pozostałych wydanych przez nia, a nierozpatrzonych jeszcze przez Sejm rozporządzeń. Tak więc rozporządzenia ROP od grudnia 1920 r. można było uchylać wyłącznie ustawa, ponieważ nie można było sprawować kontroli nad organem, który już nie istniał ${ }^{122}$. Ponadto należy zauważyć, że po ustaniu mandatu ROP jej rozporządzenia, nierozpatrzone przez Sejm, stawały się (z ustaw tymczasowych) aktami o nieograniczonej czasowo mocy prawnej i jako takie mogły być derogowane tylko aktem prawnym co najmniej tej samej rangi.

\section{UWAGI KOŃCOWE}

Pierwszy parlament odrodzonej Rzeczypospolitej był fenomenem dziejowym tworzącym podwaliny ustrojowo-prawne systemu rządów parlamentarno-gabineto-

${ }^{118}$ R. Kraczkowski (ibidem, s. 72) podaje, że nie opublikowano czterech rozporządzeń ROP. Tymczasem analiza treści „Dziennika Ustaw” z 1920 r. pozwala doliczyć się tylko 57 rozporządzeń ROP opublikowanych na jego łamach. Sejmowi przedłożono 59 rozporządzeń, co oznaczałoby, że nie opublikowano nie czterech, lecz sześciu rozporządzeń ROP. Liczba 59 rozporządzeń przedłożonych Sejmowi przez premiera znajduje również potwierdzenie w Skorowidzu, s. 606-614.

119 Vide spr. sten. ze 166. posiedzenia SU, 24 lipca 1920 r., ł. 5-6.

${ }^{120}$ R. Kraczkowski, op. cit., s. 74.

121 Ibidem, s. 74-75. Z zestawienia losów rozporządzeń ROP sporządzonego w Skorowidzu, s. 607-614, wynika, że w komisjach zaległo 46 rozporządzeń; izba uchyliła nie trzy lecz cztery spośród nich oraz poddała częściowej zmianie nie jedno lecz trzy rozporządzenia. W sumie więc izba rozpatrzyła 13 rozporządzeń ROP, a nie 10, jak podaje R. Kraczkowski. Autor ten nie wskazuje wyraźnie podstawy źródłowej swoich obliczeń, nie powołuje się też na cytowany tu Skorowidz, który wydaje się wiarygodny.

${ }^{122}$ R. Kraczkowski, op. cit., s. 75-78. 
wych w Polsce. Wiele jego dokonań zachowywało aktualność - mimo istotnie zmienionych warunków ustrojowych — nawet do końca międzywojnia i weszło do kanonu polskiej tradycji parlamentarnej. SU zasadniczo nie mógł odwoływać się do dorobku ustrojowego I Rzeczypospolitej, z racji jego historycznej dezaktualizacji. Trzeba było zatem stworzyć nowy kształt przedstawicielstwa narodowego, niejako na surowym korzeniu, korzystając co najwyżej z wiedzy w zakresie problematyki prawno-ustrojowej posiadanej przez zasiadających w jego ławach prawników (dotyczącej porządków konstytucyjnych państw zachodnioeuropejskich) oraz doświadczeń wyniesionych przez nich oraz posłów nieposiadających przygotowania prawniczego z parlamentów państw zaborczych ${ }^{123}$. Ten kapitał społeczny okazał się bezcenny, jeśli chodzi o potrzebę nadawania kształtu normatywnego i praktycznego omówionych procedur parlamentarnych. Należy jednak zauważyć, że znaczący wkład w to dzieło wniósł również rząd Ignacego Paderewskiego, który przedłożył projekt regulaminu obrad izby (uchwalony przez nią z niewielkimi poprawkami), pracownicy Biura Sejmu oraz ci spośród posłów niezaliczonych do wymienionych grup, którzy czynnie angażowali się w prace komisji oraz postępowania sejmowe, szybko uczyli się nowych ról społecznych i wykazywali się wielką pracowitością, spędzając np. dziesiątki godzin tygodniowo w Bibliotece Sejmowej.

Sejm Ustawodawczy od samego początku swojego istnienia podjął się wykonywania wszystkich klasycznych funkcji parlamentarnych państwa konstytucyjnego, zaadaptował i twórczo przeszczepił na polski grunt szeroki zasób istotnych procedur parlamentarnych, a nawet dopracował się w tym zakresie rozwiązań bezprecedensowych na skalę europejska, jak np. w odniesieniu do przebiegu i usprawniania obrad plenarnych oraz podnoszenia efektywności prac całej izby i jej komisji ${ }^{124}$. Wszystko to na podstawie niezwykle skromnego umocowania w normach pozytywnego prawa parlamentarnego, praktycznie ograniczonego do przepisów niezbyt obszernego regulaminu. Wymagało to od organów kierowniczych izby, komisji i klubów poselskich znajomości ich odpowiedników w parlamentaryzmie zachodnioeuropejskim oraz subtelnych niekiedy tamtejszych zwyczajów i konwenansów bądź podjęcia — jak się okazało, z dużym powodzeniem - trudu stopniowego dopracowywania się rodzimych reguł proceduralnych.

123 Przez ławy konstytuanty w całym okresie jej funkcjonowania przewinęło się ogółem 451 osób pełniących mandat poselski, z czego 52 (11,5\% ogółu) z nich odbyły studia prawnicze (ponad 1/3 z nich uprawiała zawód prawniczy). W tej grupie 37 posłów miało doświadczenie parlamentarne z przedstawicielstw państw zaborców Polski (20 zasiadało uprzednio w wiedeńskiej Radzie Państwa, 10 w Sejmie Krajowym we Lwowie, czterech w Reichstagu Rzeszy, a trzech w pruskim Sejmie Krajowym). Spośród posłów reprezentujących zawody nieprawnicze doświadczenia parlamentarne posiadało 51 posłów konstytuanty (11,3\% ogółu posłów), z czego: 21 w parlamencie wiedeńskim, 17 w Sejmie Krajowym galicyjskim, po 13 w Reichstagu i rosyjskiej Dumie Państwowej oraz pięciu w Landtagu pruskim [obliczenia własne — P.A.T.].

124 Sejm w trakcie 45 miesięcy działalności odbył 342 posiedzenia plenarne (średni czas trwania posiedzenia wynosił ok. 4,5 godziny), uchwalił 606 ustaw (53,3\% ogółu zgłoszonych projektów ustaw) i blisko 1,5 tysiąca innych wniosków i rezolucji; vide P.A. Tusiński, Postępowanie..., passim. 


\section{BIBLIOGRAFIA}

\section{ŹRÓDŁA}

„Dziennik Praw Królestwa Polskiego” 1918.

„Dziennik Praw Państwa Polskiego” 1918-1919.

„Dziennik Ustaw Rzeczypospolitej Polskiej” 1919-1921.

Głąbiński S., Wspomnienia polityczne, Druk. i Księg. Sp. z O. Odp., Pelplin 1939.

„Kurier Polski” 1919-1922.

Rataj M., Wskazania obywatelskie i polityczne, Ludowa Spółdzielnia Wydawnicza, Warszawa 1987.

Sejm Rzeczypospolitej Polskiej. I kadencja 1922-1927. Spr. sten. z 16. posiedzenia, 16 lutego $1923 \mathrm{r}$.

Sejm Ustawodawczy Rzeczypospolitej Polskiej. Skorowidz rzeczowy do sprawozdań stenograficznych z posiedzeń plenarnych Sejmu pos. 1 (10.II.1919)-pos. 342 (27 XI 1922), Kancelaria Sejmu PRL, Warszawa 1972, maszynopis w Bibliotece Sejmowej.

Sejm Ustawodawczy Rzeczypospolitej Polskiej 1919-1922, druki.

Sejm Ustawodawczy Rzeczypospolitej Polskiej 1919-1922, sprawozdania stenograficzne.

Sudoł J., Wspomnienia z lat 1882-1945, t. V, maszynopis w Bibliotece Zakładu Narodowego im. Ossolińskich we Wrocławiu, sygn. 15329/I, II.

Tymczasowy Regulamin Obrad Sejmu Ustawodawczego Rzeczypospolitej Polskiej, oprac. T. Koperska, „Przegląd Sejmowy” 1993, nr 1.

Wierzbicki A., Wspomnienia, t. II, maszynopis w Bibliotece Instytutu Historii Polskiej Akademii Nauk w Warszawie.

Wierzbicki A., Wspomnienia i dokumenty (1877-1920), Państwowe Wydawnictwo Naukowe, Warszawa 1957.

Witos W., Moje wspomnienia, Ludowa Spółdzielnia Wydawnicza, Warszawa 1978.

Wojdaliński R., Relacje posła na Sejm Ustawodawczy (1919-1922), t. I-IV, maszynopis w Bibliotece Zakładu Narodowego im. Ossolińskich we Wrocławiu, sygn. 14108/II.

\section{PIŚMIENNICTWO}

Ajnenkiel A., Spór o model parlamentaryzmu polskiego do roku 1926, Książka i Wiedza, Warszawa 1972.

Banaszak B., Prawo konstytucyjne, C.H. Beck, Warszawa 2012.

Cybichowski Z., Polskie prawo państwowe na tle uwag z dziedziny nauki o państwie i porównawczego prawa państwowego, t. II, Wydawnictwo Seminarium Prawa Publicznego Uniwersytetu Warszawskiego, nr 16, Warszawa 1933.

Grodyński T., Zasady gospodarstwa budżetowego w Polsce na tle porównawczem, Polska Akademja Umiejętności, Kraków 1932.

Gwiżdż A., Burżuazyjno-obszarnicza Konstytucja z 1921 roku w praktyce, Wydawnictwo Prawnicze, Warszawa 1956.

Gwiżdż A., Formy pracy sejmów Drugiej Rzeczypospolitej, [w:] Sejmy Drugiej Rzeczypospolitej, red. A. Zakrzewski, Ludowa Spółdzielnia Wydawnicza, Warszawa 1990.

Kaczmarek Z., Wojciech Trąmpczyński, Urząd Wojewódzki w Poznaniu. Wydział Kultury i Sztuki, Poznań 1993.

Kijowski M., Udziat Sejmu i Senatu w ratyfikacji umów międzynarodowych (1919-2003), Wydawnictwo Uniwersytetu Rzeszowskiego, Rzeszów 2004. 
Komarnicki W., Polskie prawo polityczne (Geneza i system), F. Hoesick, Warszawa 1922.

Komarnicki W., Ustrój państwowy Polski współczesnej. Geneza i system, „Świt”, Wilno 1937.

Kraczkowski R., Dekretowanie ustaw w Polsce w latach 1918-1926, Wydawnictwo Sejmowe, Warszawa 1994.

Krukowski S., Geneza konstytucji z 17 marca 1921 r., Ludowa Spółdzielnia Wydawnicza, Warszawa 1977.

Krukowski S., Konstytucja Rzeczypospolitej Polskiej z 1921 r., [w:] Konstytucje Polski. Studia monograficzne z dziejów polskiego konstytucjonalizmu, t. II, red. M. Kallas, Państwowe Wydawnictwo Naukowe, Warszawa 1990.

Kulesza W.T., Uchwała Sejmu Ustawodawczego z dnia 20 lutego 1919 r. o powierzeniu Józefowi Pitsudskiemu dalszego sprawowania urzędu Naczelnika Państwa, „Przegląd Sejmowy" 2007, nr 5.

Kustra E., Proces ustawodawczy jako proces decyzyjny, „Acta Universitatis Nicolai Copernici. Prawo XII. Nauki Humanistyczno-Społeczne” 1973, z. 56.

Marszałek P.K., Rada Obrony Państwa z 1920 roku. Studium prawnohistoryczne, „Acta Universitatis Wratislaviensis" 1995, Prawo CCXXVIII.

Pietrzak M., Tryb uchwalenia konstytucji marcowej (17 marca 1921 r.), [w:] Tryby uchwalania polskich konstytucji, red. M. Wyrzykowski, Instytut Spraw Publicznych, Warszawa 1998.

Radziewanowska B., Ewolucja francuskiego systemu komisji parlamentarnych na tle porównawczym, praca doktorska: Wydział Prawa i Administracji UJ, sygn. 81/71, Archiwum Biblioteki Jagiellońskiej w Krakowie.

Rzepecki T., Sejm Rzeczypospolitej Polskiej 1919 roku, Wielkopolska Księg. Nakładowa, Poznań 1920.

Schreiner H.J., Procedury w niemieckiej tradycji parlamentarnej, „Przegląd Sejmowy” 1994, $\mathrm{nr} 4$.

Siemieński F., Uchwalanie konstytucji polskich, [w:] Przeobrażenia we współczesnym prawie konstytucyjnym, red. K. Działocha, „Acta Universitatis Wratislaviensis” 1995, Prawo CCXLVII.

Stownik języka polskiego, t. 2: L-P, Państwowe Wydawnictwo Naukowe, Warszawa 1979.

Stembrowicz J., Parlament V Republiki Francuskiej, Państwowe Wydawnictwo Naukowe, Warszawa 1963.

Stembrowicz J., Rzad w systemie parlamentarnym, Państwowe Wydawnictwo Naukowe, Warszawa 1982.

Tusiński P.A., Norma prawna i obyczaj jako podstawa wyłaniania i funkcjonowania organów kierowniczych parlamentu II Rzeczypospolitej, „Prace Naukowe Politechniki Radomskiej im. Kazimierza Pułaskiego: Ekonomika" 1999, nr 1.

Tusiński P.A., Postępowanie ustawodawcze w Sejmie i w Senacie II Rzeczypospolitej 1919-1939. Prawo - zwyczaje - praktyka parlamentarna, Politechnika Radomska, Radom 2008.

Wątor A., Działalność Zwiazku Ludowo-Narodowego w latach 1919-1922, Wydawnictwo Naukowe Uniwersytetu Szczecińskiego, Szczecin 1992.

Zieleniewski L., Regulamin Senatu na tle regulaminów oraz praktyki izb ustawodawczych w Polsce i innych państwach, t. II, F. Hoesick, Warszawa 1933.

Zieleniewski L., Regulaminy Sejmu i Senatu, „Nowe Państwo” 1936, z. 2. 